\title{
QUEEN'S
UNIVERSITY
BELFAST
}

\section{Mass spectrometry study of lignocellulosic biomass combustion and pyrolysis withNOx removal}

Osman Ahmed, A. I. (2019). Mass spectrometry study of lignocellulosic biomass combustion and pyrolysis withNOx removal. Renewable Energy, 146, 484-496. https://doi.org/10.1016/j.renene.2019.06.155

\author{
Published in: \\ Renewable Energy
}

\section{Document Version:}

Peer reviewed version

Queen's University Belfast - Research Portal:

Link to publication record in Queen's University Belfast Research Portal

\section{Publisher rights}

Copyright 2019 the authors.

This is an open access article published under a Creative Commons Attribution-NonCommercial-NoDerivs License

(https://creativecommons.org/licenses/by-nc-nd/4.0/), which permits distribution and reproduction for non-commercial purposes, provided the author and source are cited.

\section{General rights}

Copyright for the publications made accessible via the Queen's University Belfast Research Portal is retained by the author(s) and / or other copyright owners and it is a condition of accessing these publications that users recognise and abide by the legal requirements associated with these rights.

Take down policy

The Research Portal is Queen's institutional repository that provides access to Queen's research output. Every effort has been made to ensure that content in the Research Portal does not infringe any person's rights, or applicable UK laws. If you discover content in the Research Portal that you believe breaches copyright or violates any law, please contact openaccess@qub.ac.uk. 


\section{Accepted Manuscript}

Mass spectrometry study of lignocellulosic biomass combustion and pyrolysis with NOx removal

Ahmed I. Osman

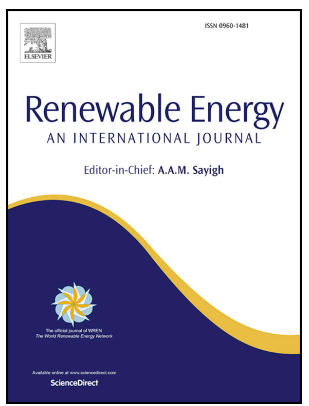

PII:

S0960-1481(19)30995-4

DOI: https://doi.org/10.1016/j.renene.2019.06.155

Reference: RENE 11887

To appear in: Renewable Energy

Received Date: 27 December 2017

Revised Date: 25 April 2019

Accepted Date: 26 June 2019

Please cite this article as: Osman Al, Mass spectrometry study of lignocellulosic biomass combustion and pyrolysis with NOx removal, Renewable Energy (2019), doi: https://doi.org/10.1016/ j.renene.2019.06.155.

This is a PDF file of an unedited manuscript that has been accepted for publication. As a service to our customers we are providing this early version of the manuscript. The manuscript will undergo copyediting, typesetting, and review of the resulting proof before it is published in its final form. Please note that during the production process errors may be discovered which could affect the content, and all legal disclaimers that apply to the journal pertain. 


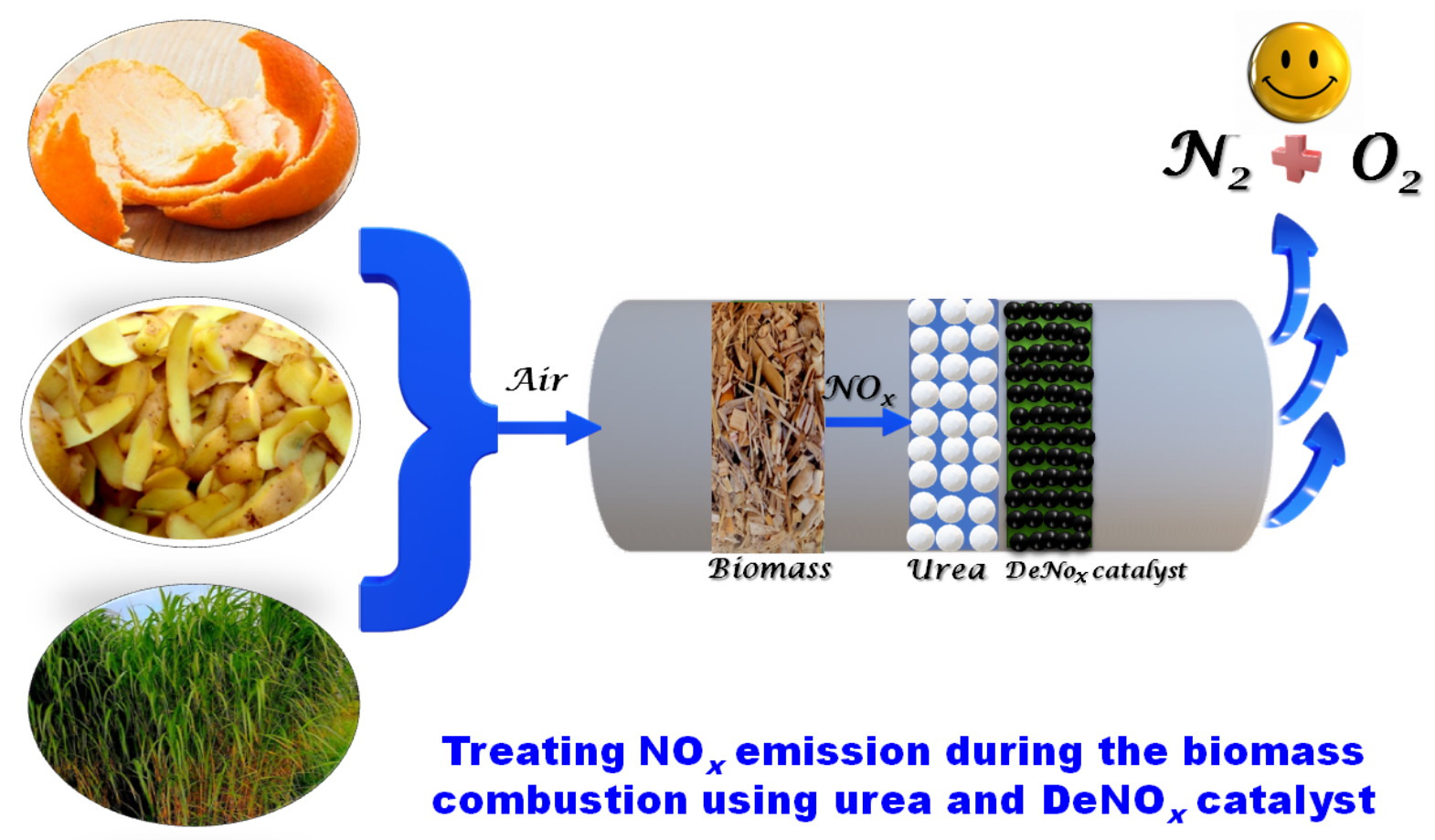


1

\section{Mass spectrometry study of lignocellulosic biomass combustion and pyrolysis with NOx removal}

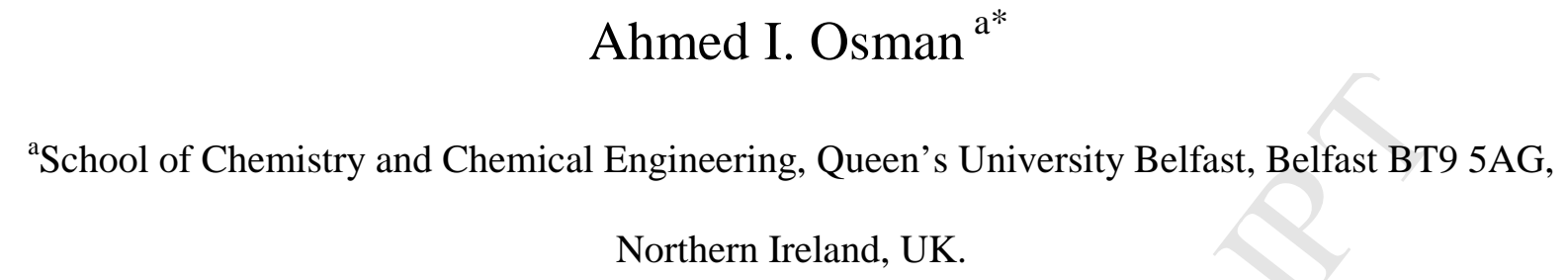

Address: School of Chemistry and Chemical Engineering, Queen's University Belfast, David Keir 


\section{Abstract}

27 Herein, a study of the thermal combustion/pyrolysis behaviour of three lignocellulosic biomass materials was tested. Alongside this an investigation on the reduction of the subsequently produced pollution emissions was carried out. The lignocellulosic biomasses (miscanthus $\times$ giganteus, orange peel waste (OPW) and potato peel waste (PPW)) were physiochemically characterized, along with in-situ gas detection from the combustion/pyrolysis processes. XRD and EDX results showed high level of inorganic salts in the bulk and surface of the samples tested which had an impact on the combustion/pyrolysis behaviour. Among the three lignocellulosic biomasses tested, OPW showed the highest higher heating value of $17.88 \mathrm{MJ} \mathrm{Kg}^{-1}$, where potato ash was the best candidate as a potential source of potassium (23.8 wt.\%) to be used in the fertiliser industry. The EDX results showed that miscanthus was the only lignocellulosic biomass to show high $\% \mathrm{Si}$ in the surface composition.This was the reason for the low-temperature melting due to the formation of low fusion-temperature silicate as a result of $\mathrm{SiO}_{2}, \mathrm{~K}, \mathrm{Cl}$ and $\mathrm{S}$. Pyrolysis experiments were conducted under pure nitrogen atmosphere, where hydrogen gas was observed in the temperature range of 580-700 ${ }^{\circ}$ C. Combustion experiments were run under air where NOx emissions are generated

41 during the combustion process. To mitigate those emissions, coupling the DeNOx catalyst with 42 urea to construct in-situ $\mathrm{NH}_{3}-\mathrm{SCR}$ system during the combustion achieved low levels of NOx emissions.

44 Keywords: Lignocellulosic biomass, Combustion, Mass spectrometer, NOx emissions.

\section{Graphical Abstract:}




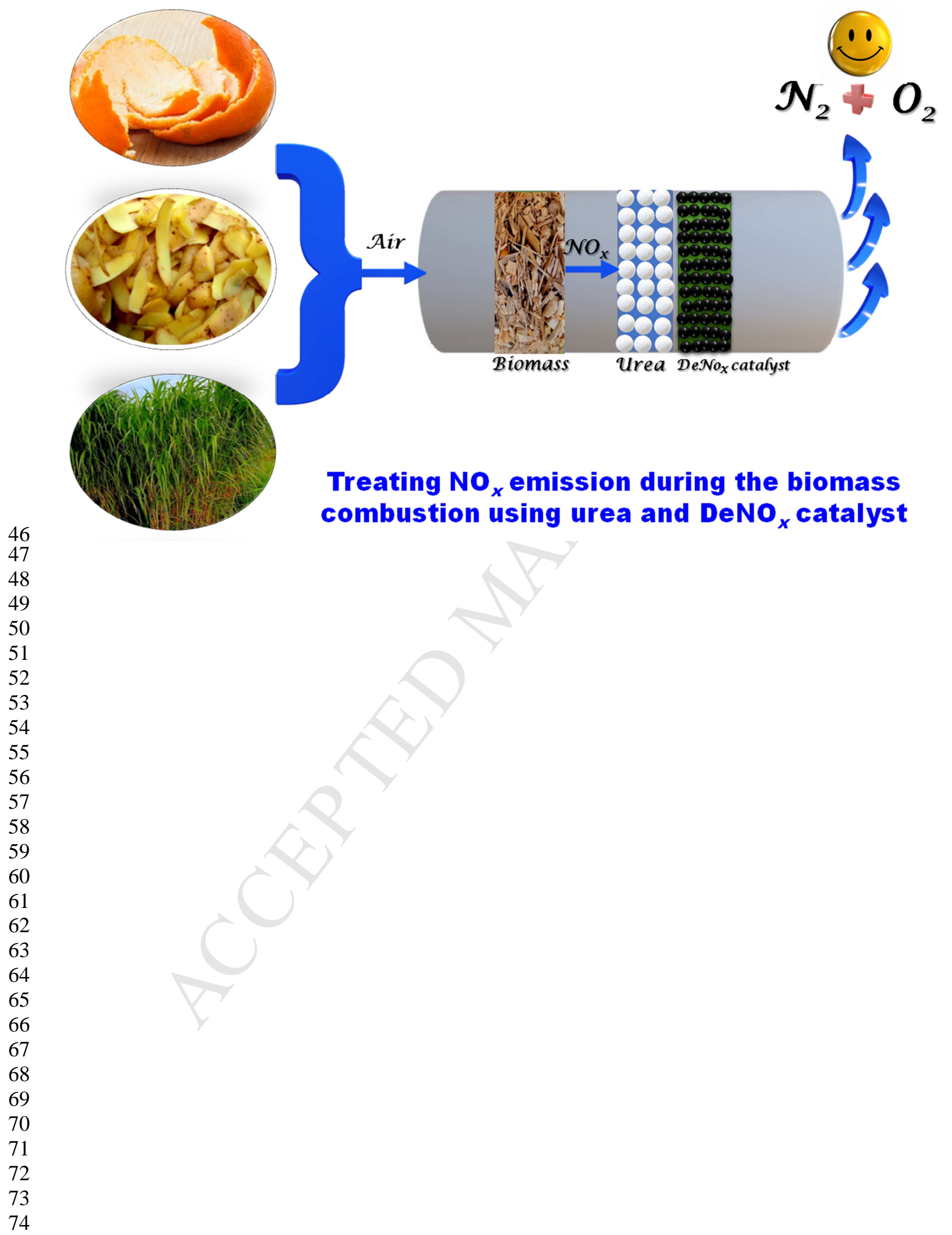




\section{Introduction}

76

Lignocellulosic biomass is considered one of the most promising energy sources due to being an environmentally friendly fuel. For instance, one tonne of lignocellulosic biomass (miscanthus) can produce 30 gallons of fuel [1]. When processed by steam gasification, it produces around 1.1 $\mathrm{m}^{3} \cdot \mathrm{Kg}^{-1}$ of gas containing more than $40 \% \mathrm{H}_{2}$ and $\mathrm{CO}$ with $\mathrm{H}_{2} / \mathrm{CO}$ ratio of $1.7 \sim 2$ as well as a low yield of tar, char, $\mathrm{CO}_{2}$ and $\mathrm{CH}_{4}$. This composition makes it suitable for the production of biofuels such as methyl alcohol, dimethyl ether (DME) or through Fischer-Tropsch (FT) processesfor the production of heavier hydrocarbons including biodiesel [2-5].

However, a comparison study of combustion efficiency between eight different biomass fuels (pine, spruce, brash, three different willow species, miscanthus and wood pellets) in a small multifuel boiler was carried out by Forbes et al.[6] who reported that the standard wood pellet showed the best overall performance with the highest output of energy per unit mass $\left(4.11 \mathrm{kWh} \cdot \mathrm{Kg}^{-1}\right)$ as an energy crop. Of the range tested miscanthus was the lowest $\left(3.7 \mathrm{kWh} . \mathrm{Kg}^{-1}\right)$. Moreover, a significant difference between these fuels was found in terms of energy output intensity, again with wood pellets being significantly higher than the miscanthus (126.9 and $83.6 \mathrm{~kW} \cdot \mathrm{h}^{-1}$, respectively).

Biomass waste such as orange peel waste (OPW) and potato peel waste (PPW) could be of great interest as an energy carrier or other applications. Potatoes are the world's fourth-largest crop after corn, rice and wheat with 21.7 billion $\mathrm{Kg}$ produced in 2011. The peeling process in a potato processing plant can generate from up to $10 \%$ PPW along with additional $15 \%$ waste from trimming, defect removal and cutting processes. The four main components of PPW are nonstarch polysaccharide $(30 \%)$, starch $(25 \%)$, acid soluble and acid insoluble lignin $(20 \%)$ and protein (18\%) along with small amounts of ash and lipids with 6 and 1\% composition, respectively [7]. On the other hand, the OPW is mainly composed of sugars, pectin, cellulose and hemicellulose along with a low content of lignin. More detailed chemical composition of the OPW was reported 
100 by Ahmed et al.[8] with moisture (40.7\%), sugars (28.48\%), crude fiber (7.8\%), ash ( $7.39 \%)$,

101 pectin (7.0\%), lignin (6.4\%) and fat (1.85\%).

102 Wu reported that there are 70,000-140,000 tonnes of PPW globally produced per annum which is 103 commonly used for producing fertilizer, low-value animal feed or as a feedstock for the 104 production of biogas via the anaerobic digestion process [9]. The PPW can also produce lactic 105 acid or phenolic acid through extraction or in the ultrasonic extraction of steroidal alkaloids.

106 Ledesma et al.[10] reported the release of hydrogen cyanide $(\mathrm{HCN})$, ammonia $\left(\mathrm{NH}_{3}\right)$, and

107 isocyanic acid (HNCO) from the thermal gas-phase cracking of coal pyrolysis tars, using a two 108 stage set up. Firstly, with a fluidised bed reactor to generate the tar, followed by a tubular flow 109 reactor in the temperature range of $600-1000^{\circ} \mathrm{C}$ to decompose the formed tars with a rapid heating 110 rate in the first stage of $10^{4} \mathrm{~K}^{-1}{ }^{-1}$. It was found that $\mathrm{HNCO}$ evolved first at a temperature above $111600^{\circ} \mathrm{C}$, where $\mathrm{HCN}$ and $\mathrm{NH}_{3}$ released in the temperature range of $700-1000^{\circ} \mathrm{C}$, with $\mathrm{NH}_{3}$ 112 evolution reached a maximum at $850^{\circ} \mathrm{C}$ [10]. Hansson et al. studied the Formation of HNCO, $113 \mathrm{HCN}$, and $\mathrm{NH}_{3}$ from the pyrolysis of bark at a temperature range of $700-1000^{\circ} \mathrm{C}$ and reported that 114 cracking of the cyclic amides is suggested to be the main reaction leading to $\mathrm{HCN}$ and $\mathrm{HNCO}$

115 [11]. Bark pyrolysis showed that quantification of $\mathrm{HCN}$ and $\mathrm{NH} 3$ was unreliable at temperature 116 up to $800^{\circ} \mathrm{C}$ due to low concentrations [11]. Other studies showed that pyrolysis of biomass

$117 \mathrm{~N}$ over $300^{\circ} \mathrm{C}$ releases $\mathrm{NH}_{3}$ and $\mathrm{HCN}$ which can be detected easily via online-FTIR or 118 offline-spectrophotometry [12-14]. Although the release of HCN may occur at higher

119 temperatures. However, due to the various types of small molecular gases in the pyrolysis 120 gases and the limitations of mass spectrometry, it may not be the best technique to 121 directly detect $\mathrm{NH}_{3}$ and $\mathrm{HCN}$. 
122 One of the major challenges of using biomass as an energy carrier is the treatment of such

123 emissions during the thermal process (combustion/pyrolysis). Nitrogen oxides (NOx) are

124 considered one of the main gas emissions during the thermal processes of biomass [6]. Therefore,

125 this kind of emissions needs to be controlled, as they have an impact on the environment and

126 human health. NOx family gases are often recognised to cause acid rain. They consist of seven

127 oxides; nitric oxide (NO), nitrogen dioxide $\left(\mathrm{NO}_{2}\right)$, nitrous oxide $\left(\mathrm{N}_{2} \mathrm{O}\right)$, dinitrogen dioxide $\left(\mathrm{N}_{2} \mathrm{O}_{2}\right)$,

128 dinitrogen trioxide $\left(\mathrm{N}_{2} \mathrm{O}_{3}\right)$, dinitrogen tetroxide $\left(\mathrm{N}_{2} \mathrm{O}_{4}\right)$ and dinitrogen pentoxide $\left(\mathrm{N}_{2} \mathrm{O}_{5}\right)$ with the

129 first three oxides considered to be the most abundant $\mathrm{NO} x$ emissions in the air. Moreover, $\mathrm{N}_{2} \mathrm{O}$

130 which is mainly produced from biogenic sources such as plants, is considered a potent greenhouse

131 gas with a global warming potential of 298 times that of $\mathrm{CO}_{2}$ with a long half-life time in the

132 atmosphere (100-150 years) [15]. Furthermore, $\mathrm{N}_{2} \mathrm{O}$ is an ozone depleting substance and it is

133 being produced and treated the same way as the rest of the NOx gases [15]. Recently, the UK

134 government reported that NOx gases are the only air emissions that have not met the agreed

135 governmental regulations thus far [16].

136 There are seven main ways to mitigate NOx emissions during fuel combustion. Firstly, by

137 reducing the peak temperature using a catalytic combustion system, reduced air preheat, air

138 staging, natural gas reburning, injecting water (steam) or using low NOx burner. The second

139 method is to reduce residence time at peak temperature by injecting air, fuel or steam. The third

140 method is a chemical reduction of NOx by using selective catalytic reduction (SCR) or selective

141 non-catalytic reduction (SNCR). The fourth method is NOx oxidation with subsequent absorption

142 using nonthermal plasma reactor or injects oxidant. The fifth method is the removal of nitrogen by

143 using oxygen instead of air or using ultra-low nitrogen fuel. The sixth method is using a sorbent in

144 the combustion chamber, while the last method is combining two or more of the last six methods

145 in order to achieve a low level of NOx emission. The most common chemical method is either 
146 HC-SCR using hydrocarbon over $\mathrm{Ag} / \mathrm{Al}_{2} \mathrm{O}_{3}$ catalyst or $\mathrm{NH}_{3}-\mathrm{SCR}$ over noble metals catalyst at

147 low temperature (urea can be used to provide the ammonia needed for this particular method).

148 Miscanthus has attracted considerable attention as an alternative candidate for a wide range of

149 applications. Currently, it is grown to some degree as a biomass energy crop for use in power

150 plants and heating combustion units. However, high ash and mineral contents in the composition

151 of miscanthus make its use as an energy source a challenge. Moreover, these minerals can have

152 the effect of lowering the melting point of miscanthus ash, causing a series of problems within

153 many combustion systems. There are ever-increasing necessities to study the thermal combustion

154 behaviour of the lignocellulosic biomass along with reducing the subsequent related pollution

155 emissions from the air.

156 The above discussion leads to the conclusion that this research area needs further investigation in

157 order to understand the gas emissions and the combustion/ pyrolysis behaviour of biomass using

158 in-situ mass spectrometry technique along with the mitigation of NOx emissions by using the in-

159 situ after-treatment catalytic system. Herein, a correlation between the chemical analysis and the

160 combustion/pyrolysis behaviour of the three different lignocellulosic biomasses (miscanthus $\times$

161 giganteus, orange peel waste and potato peel waste) was drawn via in-situ gas detection using

162 Mass spectrometer (MS) technique. To the best of the author's knowledge, this is the first detailed

163 study to correlate and understand the lignocellulosic biomass of miscanthus, OPW and PPW

164 emissions behaviour during combustion and pyrolysis along with mitigating the NOx emissions

165 using in-situ $\mathrm{NH}_{3}$-SCR system.

166 2. Materials and methods

167 2.1 Lignocellulosic biomass Material Preparation

168 The miscanthus was harvested from a 10-yr-old energy crop grown at the Agri-Food and

169 Biosciences Institute (AFBI), Environment \& Renewable Energy Centre, Hillsborough, Northern 
170 Ireland (54.453077, -6.086162) [17]. The peel wastes (OPW and PPW) were dried at $110{ }^{\circ} \mathrm{C}$ until

171 complete dryness, then crushed into a form of powder for the characterization tests and sieved to

172 obtain particles of $110-300 \mu \mathrm{m}$ size for the thermal decomposition tests.

\subsection{Lignocellulosic biomass Characterization}

Powder X-ray diffraction (XRD) was carried out using a PANalytical X'Pert Pro X-ray

diffractometer. This diffractometer was equipped with a $\mathrm{CuK}_{\alpha} \mathrm{X}$-ray source with a wavelength of $1.5405 \AA$ Á. The diffractograms were collected up to $2 \theta=80^{\circ}$. The X-ray tube was set at $40 \mathrm{kV}$ and $17940 \mathrm{~mA}$.

180 Scanning Electron Microscopy (SEM) was carried out on a FEI Quanta 250 FEG MKII with a high-resolution environmental microscope (ESEM) using XT Microscope Control software and linked to an energy-dispersive X-ray (EDX) detector. Two types of detectors were used in SEM analysis; the Everhart-Thornley Detector (ETD) which is used to detect secondary electrons

184 emitted from the sample and Back-Scattered Electron Detector (BSED). The EDX used was a 10

$185 \mathrm{~mm}^{2}$ silicon drift detector (SDD)-x-act from Oxford Instruments which utilizes Aztec® EDS analysis software. Both systems used the same chamber.

187 Brunauer-Emmett-Teller (BET) analysis was performed using a Micromeritics ASAP 2020

188 system. BET surface area and pore volume were measured by $\mathrm{N}_{2}$ adsorption and desorption 189 isotherms at liquid nitrogen temperature $\left(-196^{\circ} \mathrm{C}\right)$.

190 Compositions of the three lignocellulosic biomass samples were characterized by means of 191 proximate and ultimate analyses. Elemental (C, H and N) Analysis was performed using a Perkin 192 Elmer PE2400 CHNS/O Elemental Analyzer. The oxygen content was calculated by difference 193 from the data obtained by a Perkin Elmer PE2400 CHNS/O Elemental Analyzer machine. 
194 TGA was performed from 50 to $900{ }^{\circ} \mathrm{C}$ with different heating rates of $2.5,10,20$ and $30{ }^{\circ} \mathrm{C} . \mathrm{min}^{-1}$,

195 in a stream of dry $\mathrm{N}_{2}$ flowing at $20 \mathrm{~cm}^{3} \cdot \mathrm{min}^{-1}$, using a simultaneous thermal analysis Mettler

196 Toledo (TGA/DSC) Thermogravimetric analyzer Pyris TGA/DSC1. Changes in mass of the

197 sample were recorded during the ramping operation. Differential Scanning Calorimetry (DSC)

198 was used to determine the heat liberated in watts per gram.

The combustion/pyrolysis of the three lignocellulosic biomass experiments was conducted in a fixed bed reactor, where the output of the reactor is coupled with a mass spectrometer (MS) through a heated quartz capillary tube. In order to prevent any condensation, dissolution or adsorption on the tube wall, all of the lines were heated to $150{ }^{\circ} \mathrm{C}$, where the evolved gas mixtures were then directly fed to the mass spectrometer. The MS (Hiden Analytical instrument) performed under vacuum and in-situ detecting the characteristic fragment ion intensity of the evolved gas according to its mass to charge ratio $(\mathrm{m} / \mathrm{z})$ qualitatively. The selected ion recording mode was used to detect the MS signals of certain molecular ions marked accurately for the representative gas species such as $m / z=84$ (Krypton), $m / z=16$ (oxygen), $m / z=43$ (acetic acid), $m / z=78$ (benzene), $m / z=44$ (carbon dioxide), $m / z=27$ (ethane), $m / z=2$ (hydrogen), $m / z=13$ (methane), $m / z=31$ (methyl alcohol), $\mathrm{m} / z=64$ (sulphur dioxide), $\mathrm{m} / z=76$ (carbon disulphide), $\mathrm{m} / \mathrm{z}=26$

212 (propane), $m / z=30$ (nitrogen dioxide, nitric oxide), $m / z=45$ (nitrous oxide), $m / z=94$ (phenol), $m / z=91$ (toluene), $m / z=18$ (water), $m / z=29$ (acetaldehyde), $m / z=57$ (hexane) and $m / z=42$

214 (pentane). In fact the molecular ion of both $\mathrm{N}_{2} \mathrm{O}$ and $\mathrm{CO}_{2}$ is 44 , however, their ion peaks are 215 different where $\mathrm{N}_{2} \mathrm{O}$ is 44,30 and 28 and $\mathrm{CO}_{2}$ is 44,28 and 16.

\section{3. Results and Discussion}

\section{$217 \quad 3.1$ Lignocellulosic biomass characterisation}




\subsubsection{XRD analysis}

219 The XRD diffractogram patterns of the orange peel waste (OPW) and potato peel waste (PPW) are shown in Figure 1 (a) along with their ashes in Figure 1 (b). The OPW and PPW diffractograms showed two different phases; amorphous and crystalline cellulose. In previous work [18], miscanthus showed mainly crystalline cellulose (JCPDS data 03-0289) with diffraction lines at $2 \theta=22^{\circ}$ corresponding to the crystallographic plane (002). It is obvious from Figure 1 (a) that the crystalline cellulose is much lower in the case of OPW and PPW compared to the miscanthus. The crystallinity index gives the measure of crystalline cellulose for amorphous regions. The \% CRI was given according to equation 1

$$
\% C R I=\frac{\left(I_{002}-I_{a m}\right)}{I_{002}} \times 100
$$

(Equation 1)

Where: $I_{002}:$ is the highest peak (002) intensity of the crystalline fraction at $2 \theta=22^{\circ}$

$I_{a m}:$ is the low-intensity peak of the amorphous region at $2 \theta=18^{\circ}$

230 The \% CRI values calculated for miscanthus, OPW and PPW according to equation 1 were 77.1, 46.0 and $24.1 \%$, respectively. Bicu and Mustata calculated the \% CRI for orange peel which showed $43.7 \%$ and this is in line with our results [19]. They attributed the low cellulose crystallinity to the high amorphous portion and consequently greater permeability to water and chemicals for the orange peel. PPW showed the lowest crystalline cellulose among the series of the three lignocellulosic samples with $24.1 \%$ CRI.

236 Figure 1 (b) shows the XRD pattern of orange and potato ash. Like the miscanthus ash in the previous study, both orange and potato ash showed mainly potassium hydrogen disilicate $\left(\mathrm{KHSi}_{2} \mathrm{O}_{5}\right.$ at $2 \theta=28.4$ and 32.2$)$ and potassium chloride $(\mathrm{KCl}$ at $2 \theta=40.6,50.25,58.6$ and 66.5) phases. Orange ash showed more $\mathrm{CaCO}_{3}(2 \theta=33.8)$ than that of potato ash [20]. Both samples

240 showed also diffraction lines corresponding to $\mathrm{K}_{2} \mathrm{SO}_{4}(2 \theta=21.6), \mathrm{K}_{4} \mathrm{H}_{2}\left(\mathrm{CO}_{3}\right)_{3} .1 \frac{1}{2} \mathrm{H}_{2} \mathrm{O}(2 \theta=21.6$, $23.8,30.8,36.8$ and 45.03), crystalline silica $\left(\mathrm{SiO}_{2}\right.$ at $\left.2 \theta=26.2\right)$ and $\mathrm{KHCO}_{3}(2 \theta=29.4)[21]$. 

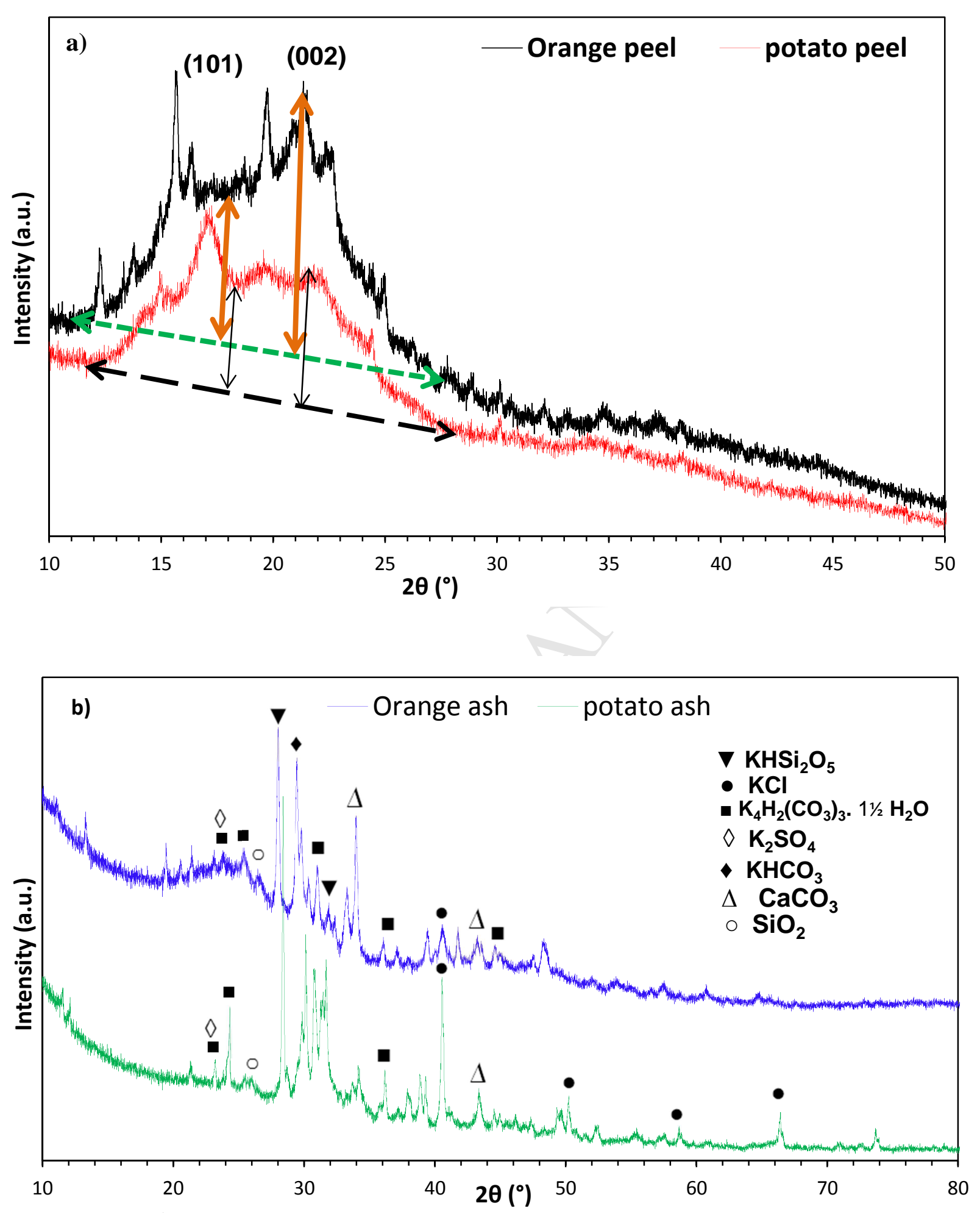

244 Figure 1: XRD patterns of orange and potato peel waste (OPW and PPW) (a) and orange and

245 potato ash (b) samples. 


\subsubsection{SEM-EDX analysis}

249 The SEM images of OPW and PPW along with their ashes using the backscattered electron 250 detector (BSED) are shown in Figure 2. The BSED is used to measure the backscattered electrons 251 from the sample, where the elements of higher atomic number appear brighter in the image due to 252 emitting a large number of back-scattered electrons (BSE). OPW and PPW samples showed few

253 lighter spots as those samples are mainly carbon and oxygen only with traces of heavy elements. It 254 is obvious that orange and potato ash images (Figure $2(c, d)$ showed more lighter spots than that of OPW and PPW (Figure $2(a, b)$ which indicates the presence of inorganic salts (heavier element than carbon) such as $\mathrm{KHSi}_{2} \mathrm{O}_{5}$ and $\mathrm{KCl}$ as shown from the $\mathrm{XRD}$ analysis of the ash samples. 
a)

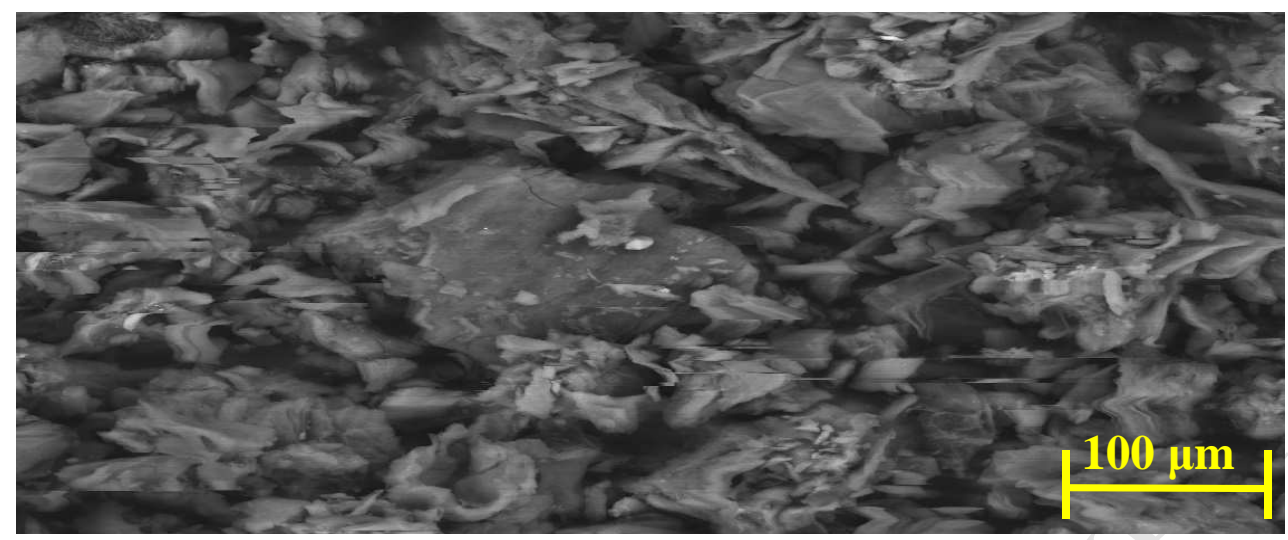

b)

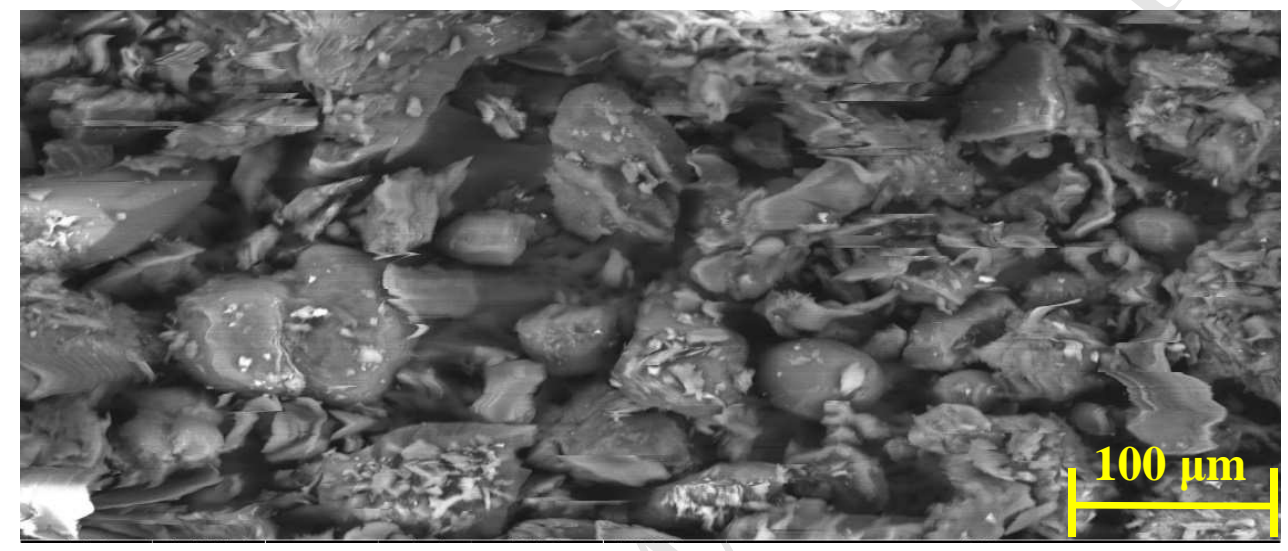

c)

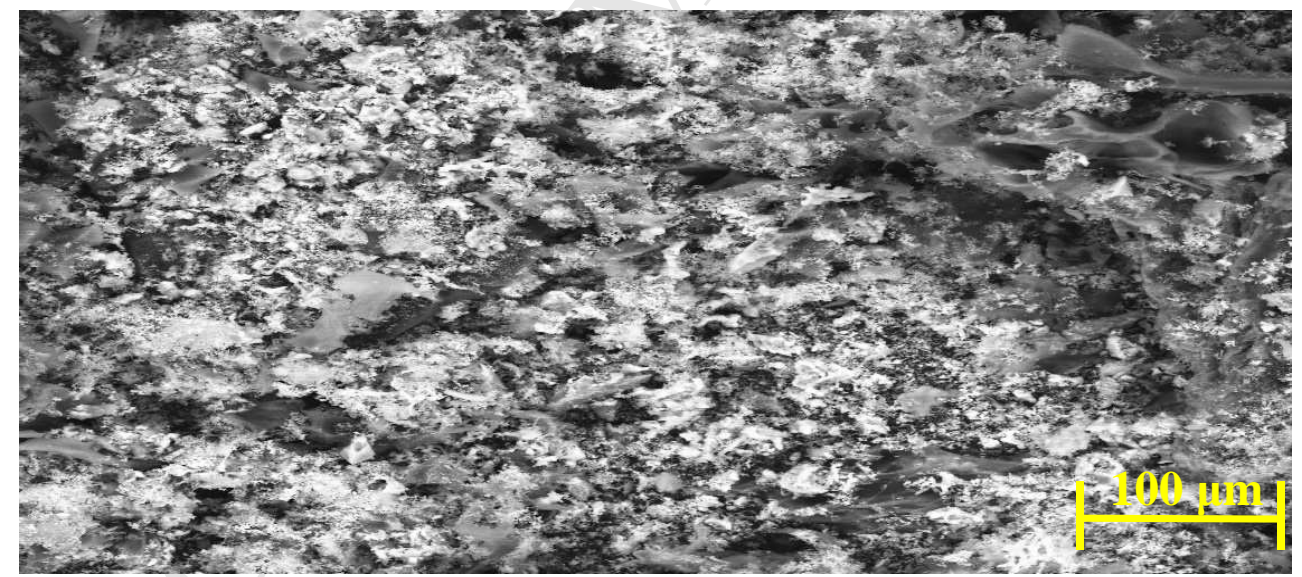

d)

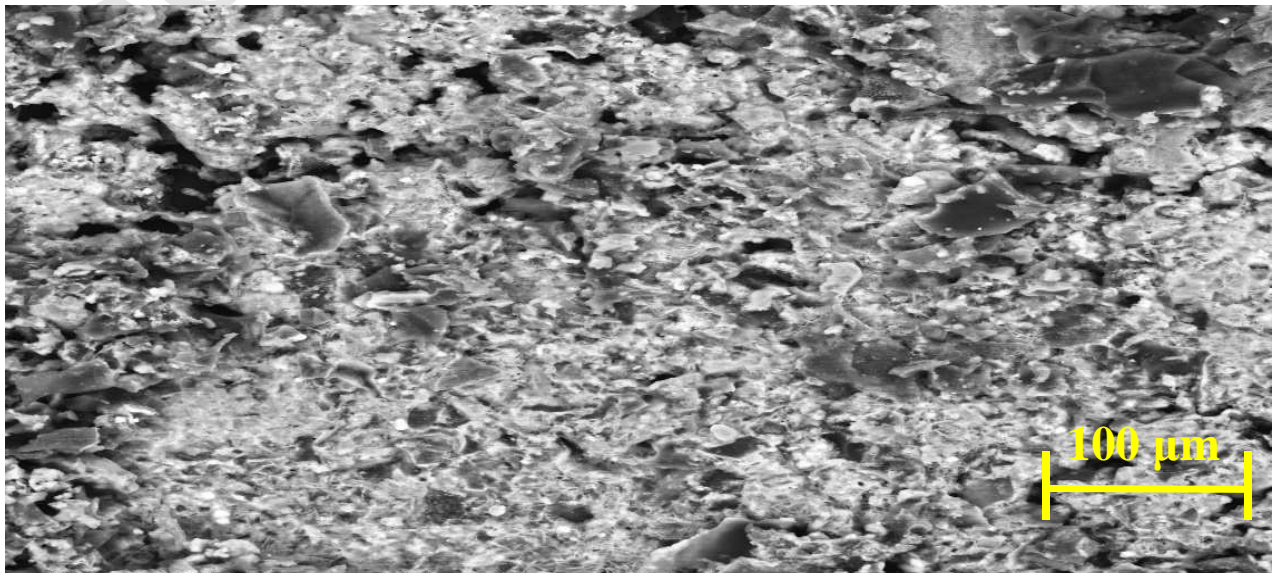

269 Figure 2: SEM images of OPW (a), PPW (b), orange ash (c) and potato ash (d). 
270 The EDX analysis revealed the chemical composition of OPW and PPW as shown in Figure 3 and

271 Table 1. It is obvious that both samples are mainly composed of carbon $(\sim 60 \mathrm{wt} . \%)$ and oxygen 272 ( 40 wt.\%) with traces of potassium (0.7-2.3 wt.\%), calcium (0.3 wt.\%) and sulphur (0.2 wt.\%).

273 Interestingly, miscanthus is the only lignocellulosic biomass in this study to show high silicon (0.6

274 wt.\%) in the composition which is six times higher than the other biomass samples as shown in

275 Table 1. The highest percentage compositions of the inorganic salts in the OPW were observed for 276 potassium and calcium with a $\mathrm{K} / \mathrm{Ca} \%$ ratio of 2.33 , which is in agreement with the ratio reported 277 by Santos et al.[22] of 2.15 .

278

279

280

281

282

283

284

285

286 

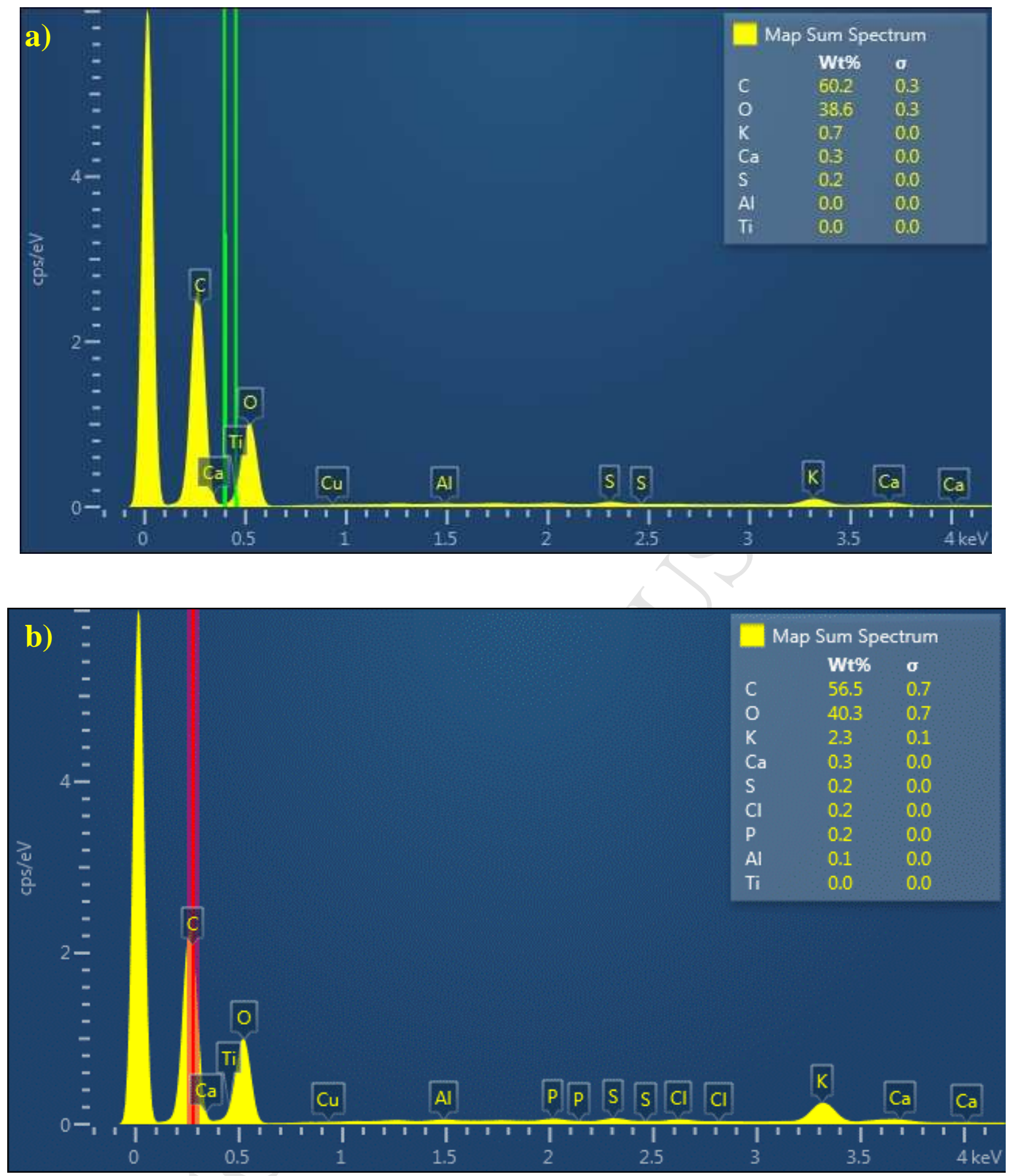

287 Figure 3: EDX data of orange peel (a), potato peel (b) samples.

289 The EDX data of the orange and potato ashes are shown in Figure 4. It is obvious that the

290 inorganic salts are dramatically increased compared to the wt.\% composition shown in Figure 3.

291 For example, the potassium and calcium \% composition in orange ash showed 17.5 and 7.6 wt.\%,

292 respectively. While in potato ash potassium and chloride \% composition showed 26.6 and 3.3 


\section{ACCEPTED MANUSCRIPT}

293 wt.\%, respectively. It is worth noting that the potassium \% composition in dry miscanthus plant

294 was 0.9 wt.\%, while in the miscanthus ash, it increased to reach 23.8 wt.\%. The inference being

295 that potato ash is the best candidate among that the three lignocellulosic biomass of being used as

296 a potential source of potassium in the fertilizer industry with 23.8 wt.\% of its composition is

297 potassium. The EDX results are in agreement with the SEM and XRD results that showed the

298 presence of inorganic salts in the ash samples.
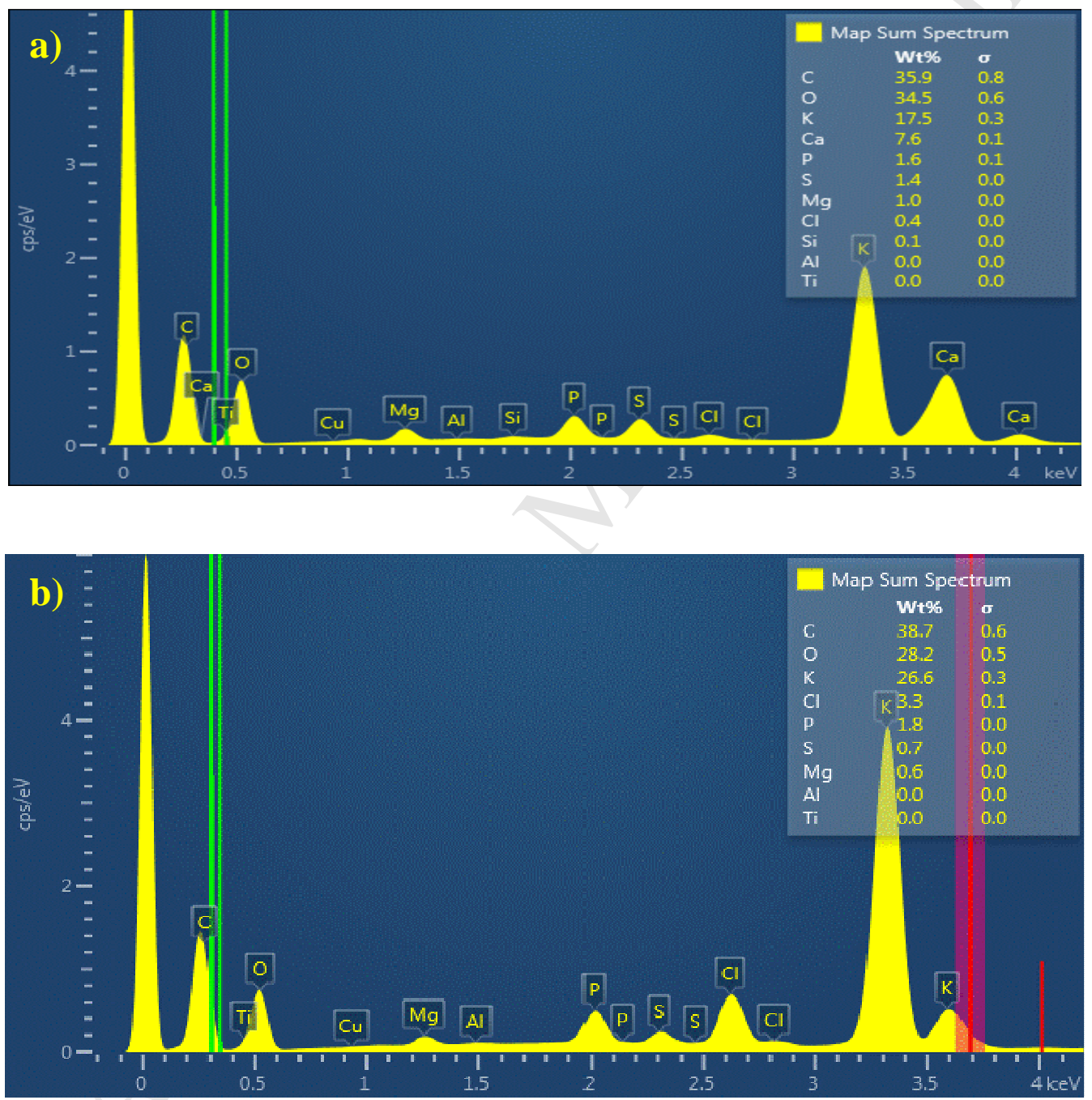

299 Figure 4: EDX data of orange ash (a), potato ash (b) samples. 


\subsubsection{TGA/DSC analyses}

304 The TGA $(a, c)$ and DSC (b, d) curves of OPW and PPW under nitrogen and air atmosphere,

305 respectively, are shown in Figure 5. The TGA curves of the thermal pyrolysis (under $\mathrm{N}_{2}$ 306 atmosphere) of OPW and PPW showed \% weight loss of 74.75 and $72.81 \%$, respectively, which is 307 slightly lower than that of miscanthus in previous work (72.5\%) [18]. The rate of the $\%$ weight 308 loss in OPW is slower than that of PPW as shown in Figure $5(\mathrm{a}, \mathrm{c})$. The DSC curves of the 309 thermal combustion (under an air atmosphere) of OPW and PPW showed in Figure 5 (b, d) with 310 two combustion stages at temperature ranges of $220-370^{\circ} \mathrm{C}$ and $410-650^{\circ} \mathrm{C}$. It is not surprising the 311 two combustion peaks were shifted toward higher temperatures with increasing the heating rate.

312 The calculated ignition and burnout temperatures along with the heat released by the combustion 313 of the three studied lignocellulosic biomass are shown in Table 1, which again all dramatically increased with increasing the heating rates. For instance, the ignition temperatures of miscanthus, OPW and PPW were slightly increased by 24,25 and $23^{\circ} \mathrm{C}$, respectively, with increasing the

316 heating rates from 2.5 to $30{ }^{\circ} \mathrm{C} \cdot \mathrm{min}^{-1}$ as shown in Figure S1 and Table 1. On the other hand, the 317 burnout temperature of miscanthus, OPW and PPW was significantly increased by 112,157 and $318160^{\circ} \mathrm{C}$, respectively with increasing the heating rates by the same value as shown in Figure S2 and 319 Table 1. Similarly, the heat liberated in $\mathrm{W} \cdot \mathrm{g}^{-1}$ of miscanthus, OPW and PPW was dramatically increased by approximately ten times with increasing the heating rates by the same value in the

321 three lignocellulosic biomass samples from around 500 to $5000{\mathrm{~W} . \mathrm{g}^{-1}}$ as shown in Table 1 and

322 Figure $\mathrm{S} 3$. The elemental $(\mathrm{C}, \mathrm{H}$ and $\mathrm{N})$ analysis is shown in Table 1, which revealed that the \% $\mathrm{C}$,

$323 \mathrm{H}, \mathrm{N}$ and $\mathrm{O}$ were in the range of $41-45 \%, 5.7-5.9 \%, 1.2-1.8 \%$ and $47-50 \%$, respectively along with minor contribution of sulphur $\sim 0.2 \%$, this is agreement with the previous publication [18]. The surface area measurement the three lignocellulosic biomass is shown in Table 1. It is obvious that they showed low surface areas of approximately $17 \mathrm{~m}^{2} \cdot \mathrm{g}^{-1}$ with a pore size of $16 \mathrm{~A}^{\mathrm{o}}$. 

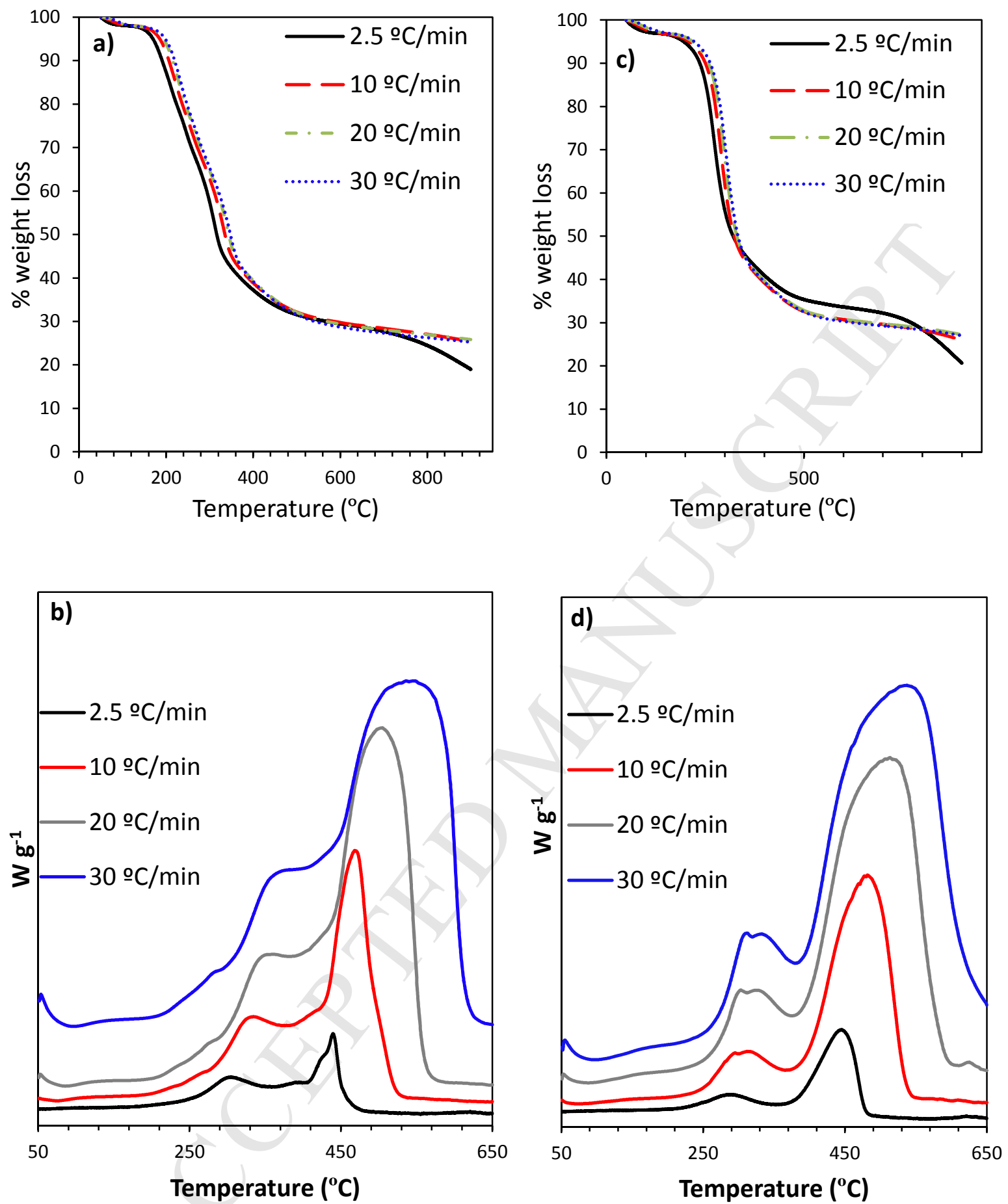

329 Figure 5: TGA curves of OPW (a) and PPW (c) under nitrogen atmosphere (20 $\left.\mathrm{ml}^{\mathrm{min}}{ }^{-1}\right)$ along 330 with the DSC curves of OPW (b) and PPW (d) under air atmosphere $\left(20 \mathrm{ml} \cdot \mathrm{min}^{-1}\right)$. 
ACCEPTED MANUSCRIPT

332 Table 1: Physicochemical characterisations of miscanthus, OPW and PPW samples.

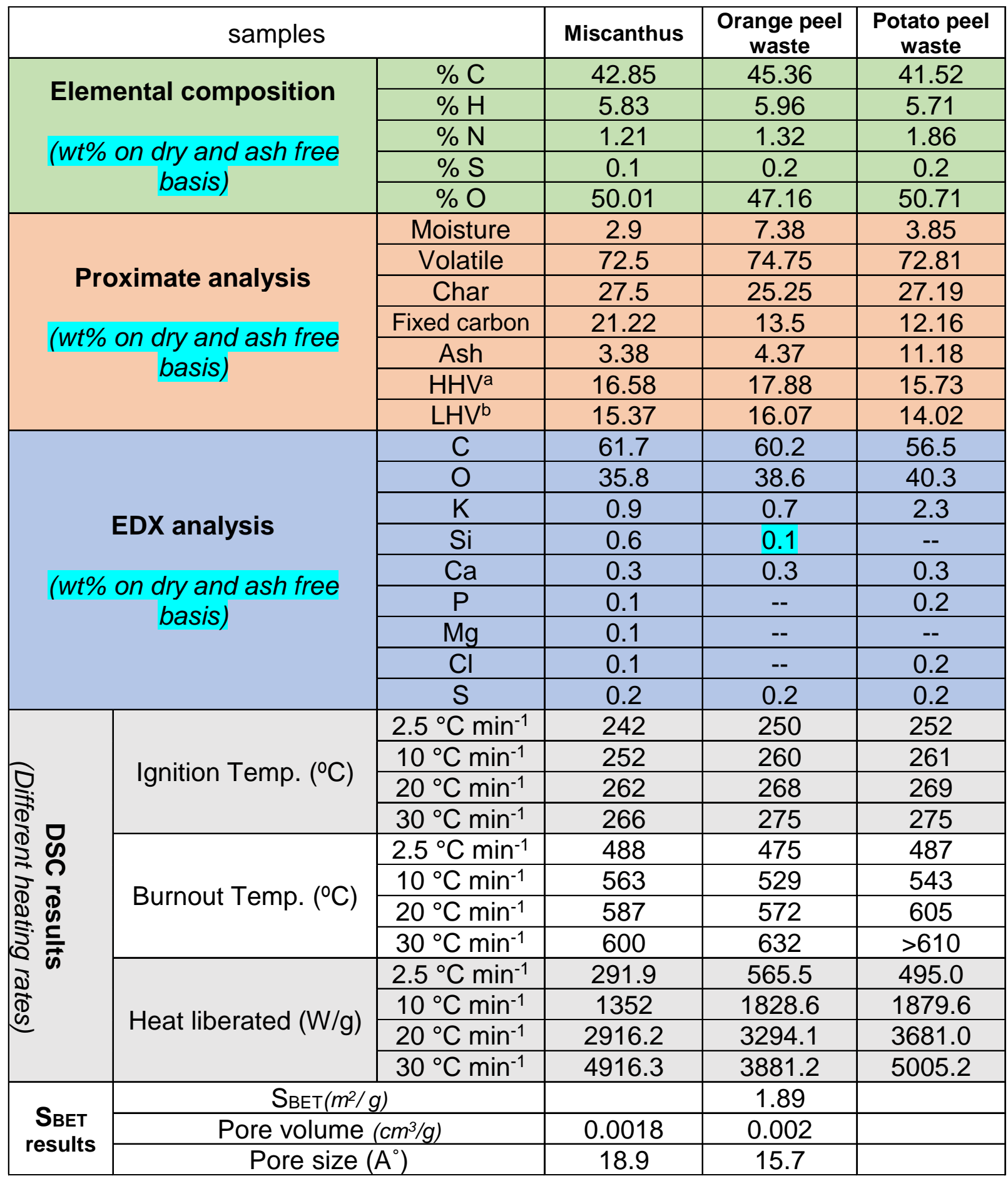

333

$334{ }^{a}$ High heating value ( $\mathrm{kJ} . \mathrm{g}^{-1}$ dry feedstock) in $\mathrm{MJ}^{\mathrm{kg}} \mathrm{kg}^{-1}$

$335{ }^{b}$ Low heating value ( $\mathrm{KJ} \mathrm{g}^{-1}$ dry feedstock) in $\mathrm{MJ} \mathrm{kg}^{-1}$

336 
3.2 Mass spectrometer analysis of lignocellulosic combustion/pyrolysis:

\section{3.2.1 Miscanthus combustion under air atmosphere:}

339 The in-situ MS profile for the gases evolved during the combustion of miscanthus under air

340 atmosphere is shown in Figure 6. As mentioned in the introduction, that there are seven nitrogen

341 oxides species, however, $\mathrm{N}_{2} \mathrm{O}, \mathrm{NO}$ and $\mathrm{NO}_{2}$ are the most abundant nitrogen oxide species in the

342 air. It is obvious that nitrous oxide shows the highest level of gas emissions during miscanthus

343 combustion as shown in Figure 6. It is well known that nitrous oxide is mainly produced through

344 biogenic sources such as plants [15], so it is not surprising that nitrous oxide showed the highest

345 level of emissions, followed by water $\left(\mathrm{H}_{2} \mathrm{O}\right)$ and carbon dioxide $\left(\mathrm{CO}_{2}\right)$. Forbes et al.[6] studied the

346 combustion of miscanthus and reported that NOx is one of the two main gases emissions. The low

347 level of gas emissions is shown in the inset, where it showed the presence of nitric oxide (NO),

348 nitrogen dioxide $\left(\mathrm{NO}_{2}\right)$, oxygen $\left(\mathrm{O}_{2}\right)$, Acetaldehyde $\left(\mathrm{CH}_{3} \mathrm{CHO}\right)$, acetic acid $\left(\mathrm{CH}_{3} \mathrm{COOH}\right)$ and

349 hydrogen $\left(\mathrm{H}_{2}\right)$ emissions with traces of benzene. Miscanthus was the only lignocellulosic sample

350 to melt during the combustion, this is in agreement with the the EDX results that showed

351 miscanhus was the only lignocellulosic biomass to show $\% \mathrm{Si}$ in the surface composition. This

352 was the reason for the low temperature melting behaviour of miscanthus herein. 


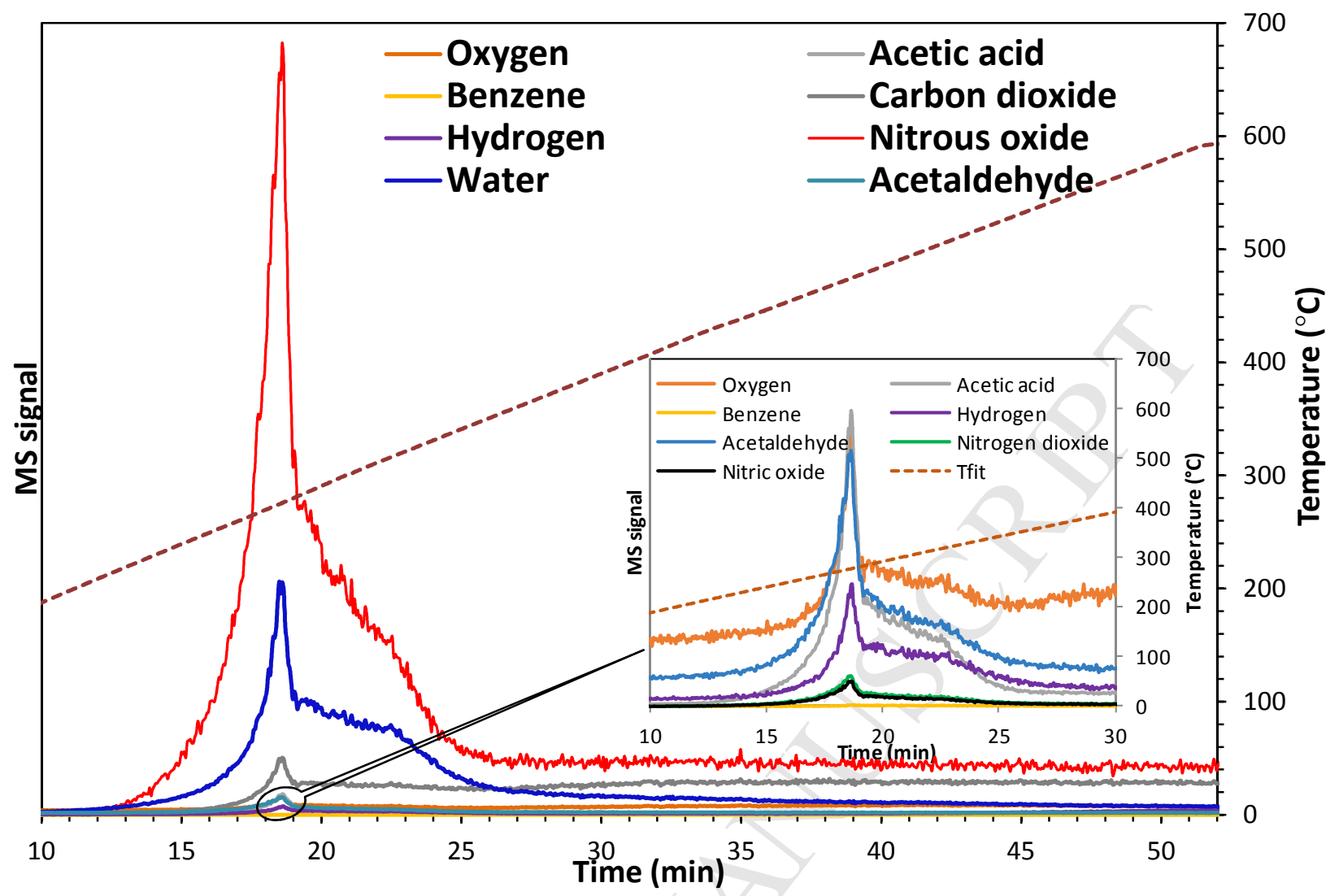

Figure 6: Mass spectrum profile of the gases released during miscanthus combustion under air atmosphere with a temperature ramp of $10^{\circ} \mathrm{C} \cdot \mathrm{min}^{-1}$. The temperature is shown in a dashed line.

\subsubsection{Miscanthus pyrolysis under nitrogen atmosphere:}

362 Similarly, miscanthus pyrolysis using nitrogen atmosphere (Figure 7) showed again the main gasemissions are $\mathrm{N}_{2} \mathrm{O}$ and $\mathrm{H}_{2} \mathrm{O}$. On the other hand, traces of $\mathrm{CO}_{2}$ was detected under the

364 pyrolysis conditions and two large $\mathrm{H}_{2}$ peaks were observed at a temperature of 580 and $700^{\circ} \mathrm{C}$.

365 The low level of gas emissions (the inset) showed the presence of $\mathrm{CO}_{2}$, hydrocarbons ( methane

366 and ethane), acetic acid, methyl alcohol and hydrogen with traces of nitrogen oxides (NO and $\left.367 \quad \mathrm{NO}_{2}\right)$. 


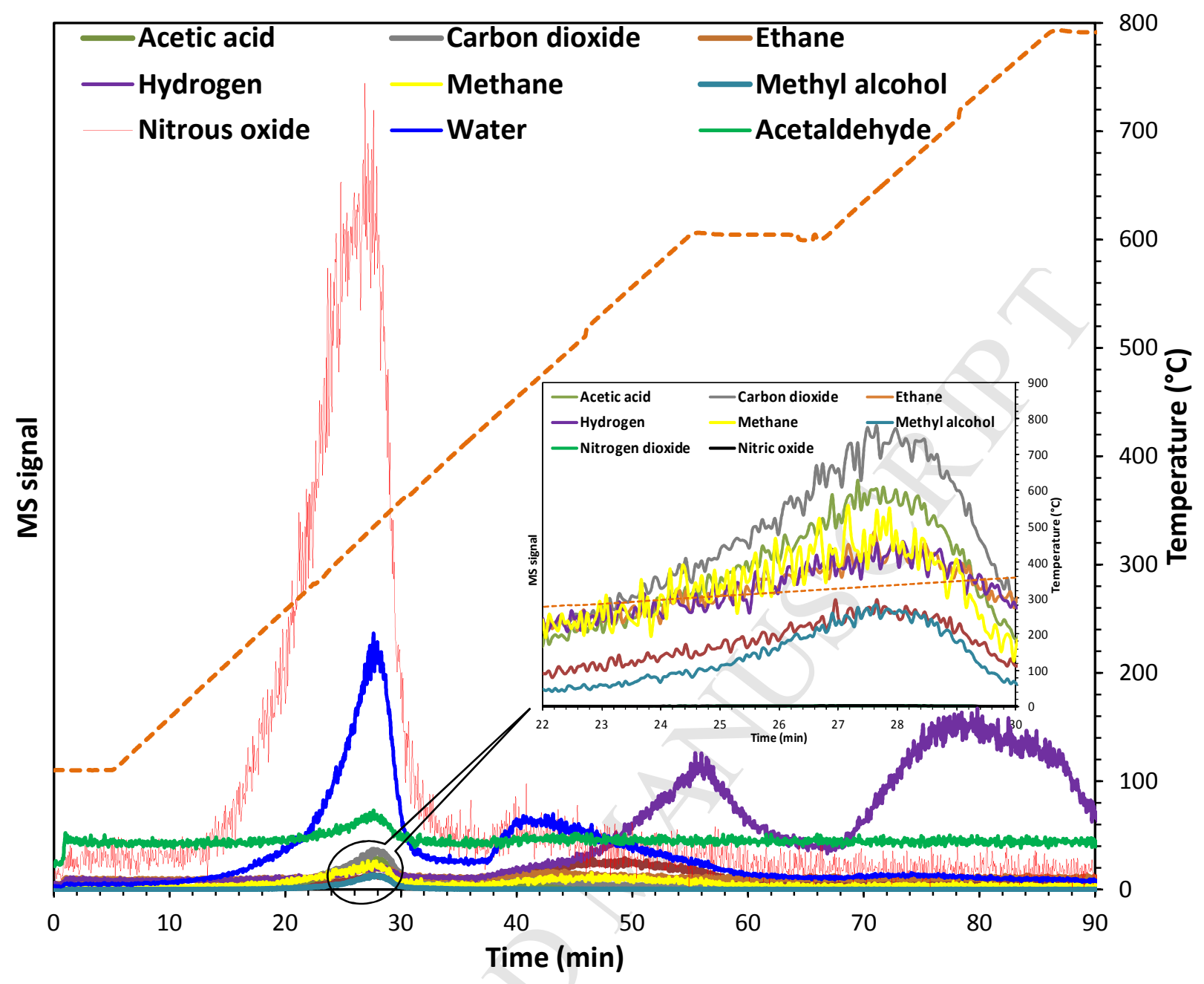

Figure 7: Mass spectrum profile of the gases released during miscanthus pyrolysis under nitrogen with a temperature ramp of $10{ }^{\circ} \mathrm{C} \cdot \mathrm{min}^{-1}$. The temperature is shown in a dashed line.

\subsubsection{Miscanthus combustion under oxygen atmosphere:}

372 Miscanthus combustion under an oxygen atmosphere (Figure 8) showed similar emissions

373 behaviour as in the combustion under air atmosphere with the main emissions being $\mathrm{N}_{2} \mathrm{O}, \mathrm{H}_{2} \mathrm{O}$

374 and $\mathrm{CO}_{2}$ with two stages of combustion at a temperature of 282 and $349{ }^{\circ} \mathrm{C}$ and this is in

375 agreement with the DSC results in Figure 5. The low level of gas emissions (the inset) showed the

376 presence of acetic acid, methane, acetaldehyde and hydrogen with traces of nitrogen oxides (NO

377 and $\mathrm{NO}_{2}$ ). 


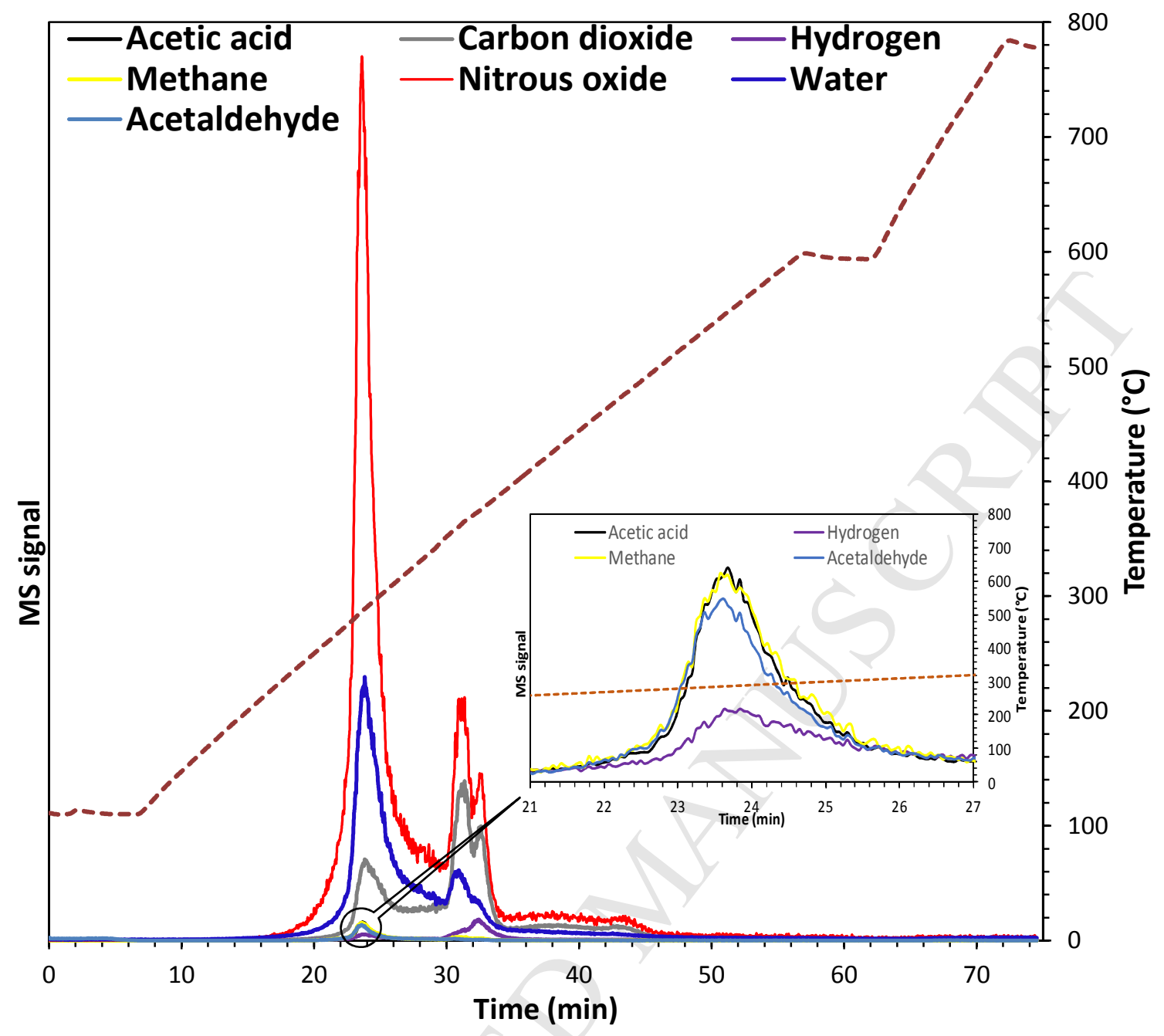

379 Figure 8: Mass spectrum profile of the gases released during miscanthus combustion under oxygen atmosphere with a temperature ramp of $10{ }^{\circ} \mathrm{C} \cdot \mathrm{min}^{-1}$. The temperature is shown in a dashed line. 


\subsubsection{Miscanthus biochar combustion under air atmosphere:}

The MS profile for the gas emissions during the combustion of miscanthus biochar is shown in

Figure 9. Again, the highest level of gas emissions was shown for $\mathrm{N}_{2} \mathrm{O}$. However, it was followed by $\mathrm{CO}_{2}$ and $\mathrm{O}_{2}$ gases with traces of $\mathrm{H}_{2} \mathrm{O}, \mathrm{CH}_{3} \mathrm{CHO}$ and $\mathrm{H}_{2}$ emissions.

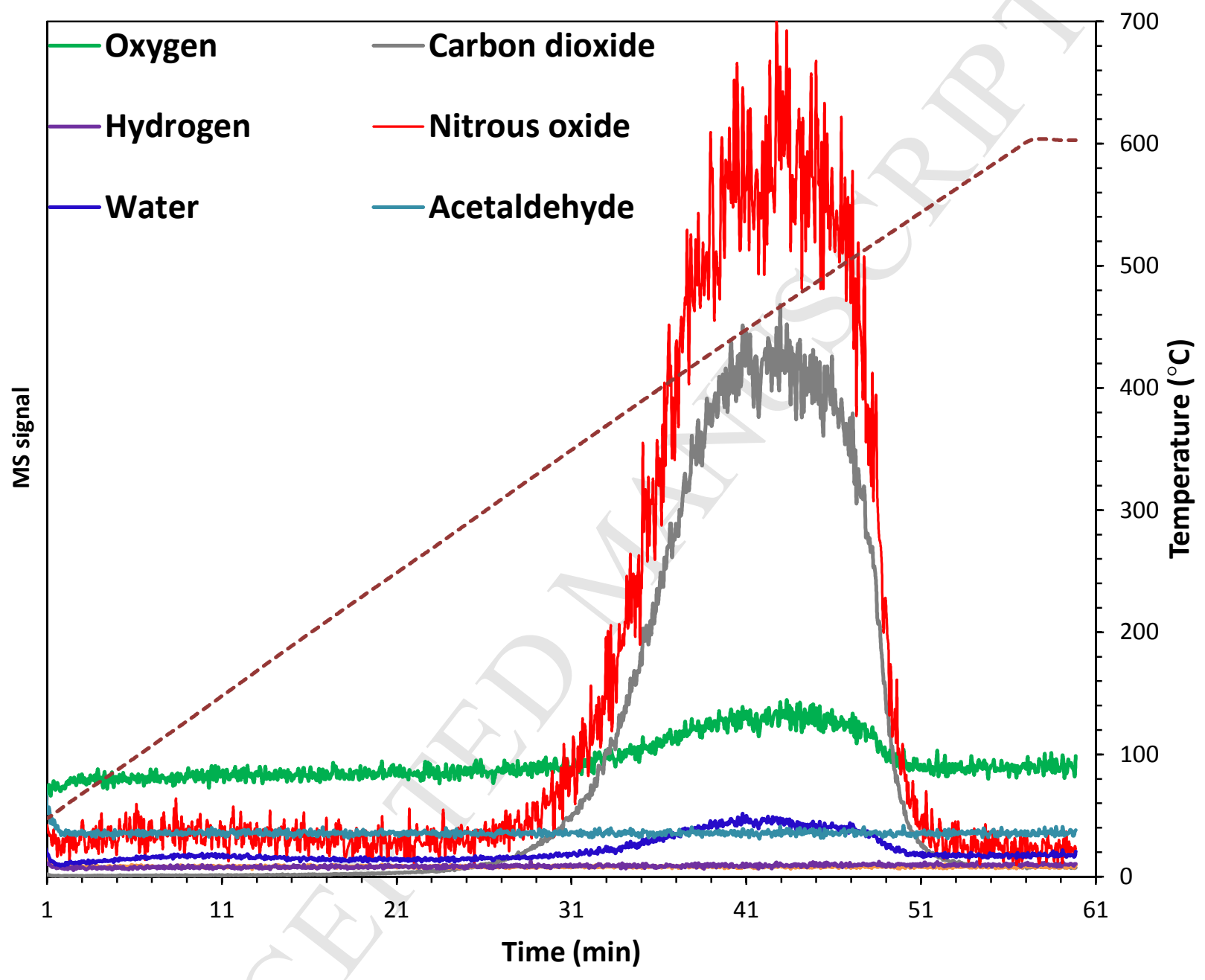

391

Figure 9: Mass spectrum profile of the gases released during miscanthus biochar combustion under an air atmosphere with a temperature ramp of $10^{\circ} \mathrm{C} \cdot \mathrm{min}^{-1}$. The temperature is shown in a dashed line. 


\section{ACCEPTED MANUSCRIPT}

\subsubsection{Orange peel waste combustion under air atmosphere:}

398 The in-situ MS profile for the gases evolved during the combustion of OPW under air atmosphere

399 is shown in Figure 10. It is obvious that the combustion occurred in two stages at a temperature 400 range of $160-370^{\circ} \mathrm{C}$ and $440-600^{\circ} \mathrm{C}$. The MS profile showed that with the main emissions are

$401 \mathrm{~N}_{2} \mathrm{O}, \mathrm{H}_{2} \mathrm{O}, \mathrm{CO}_{2}$ and $\mathrm{O}_{2}$. The low level of gases emission (the inset) showed the presence of $\mathrm{CH}_{4}$,

$402 \mathrm{H}_{2}$ and ethane with traces of $\mathrm{CH}_{3} \mathrm{CHO}$ and nitrogen oxides ( $\mathrm{NO}$ and $\mathrm{NO}_{2}$ ). Zapata et al. [23]

403 reported that the thermal degradation firstly started by the depolymerization and thermal cracking

404 of the functional groups of hemicellulose in the temperature range of $150-250^{\circ} \mathrm{C}$, followed by the 405 defunctionalization, depolymerization and chain breaking of cellulose in the temperature range of $406250-360^{\circ} \mathrm{C}$. Finally, lignin degradation occurred at the temperature range of $380-585^{\circ} \mathrm{C}$. 


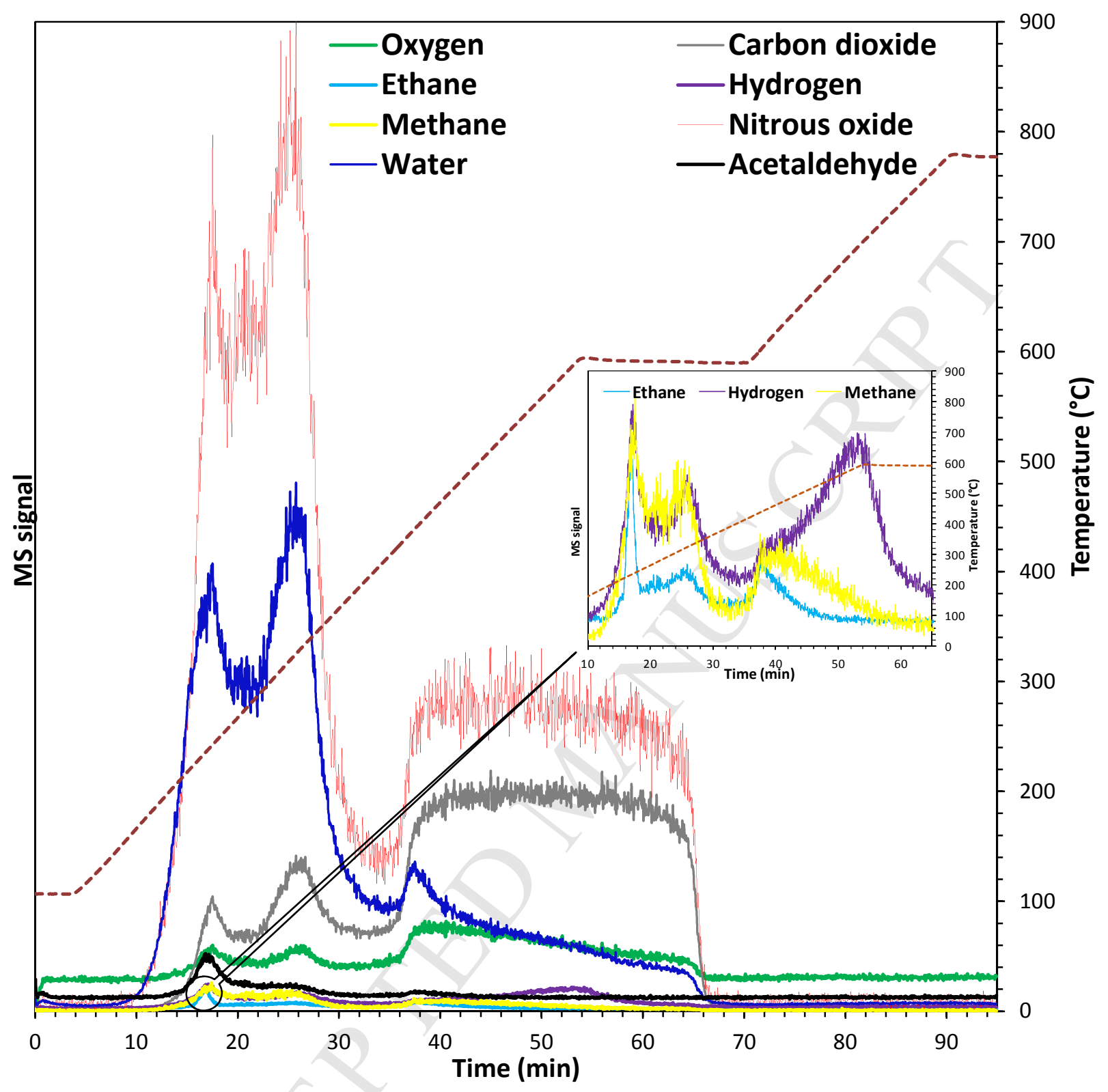

Figure 10: Mass spectrum profile of the gas released during orange peel waste combustion under a dashed line. 


\section{ACCEPTED MANUSCRIPT}

\section{3.2.6 Potato peel waste combustion under air atmosphere:}

415 The in situ MS profile for the gases evolved during the combustion of PPW under air atmosphere

416 is shown in Figure 11. Unlike the OPW combustion which occurred in two stages, the combustion

417 of PPW showed two main combustion stages at temperature ranges of $200-300^{\circ} \mathrm{C}$ and $400-500^{\circ} \mathrm{C}$

418 along with a small combustion peak at high temperature $\left(>700^{\circ} \mathrm{C}\right)$. Again, the MS profile showed

419 that with the main emissions are $\mathrm{N}_{2} \mathrm{O}, \mathrm{H}_{2} \mathrm{O}, \mathrm{CO}_{2}$ and $\mathrm{O}_{2}$, while The low level of gas emissiosn

420 (the inset) showed the presence of $\mathrm{CH}_{3} \mathrm{CHO}, \mathrm{CH}_{3} \mathrm{COOH}, \mathrm{CH}_{4}, \mathrm{H}_{2}$ and $\mathrm{C}_{2} \mathrm{H}_{6}$ with traces of and

421 nitrogen oxides ( $\mathrm{NO}$ and $\mathrm{NO}_{2}$ ). The results are in agreement with the work done by Liang et al. [7]

422 who reported the presence of $\mathrm{CH}_{3} \mathrm{CHO}$ and $\mathrm{CH}_{3} \mathrm{COOH}$ with a relative abundance of 2.89 and

$42314 \%$ during the pyrolysis of PPW using GC-MS technique. It is worth noting that the total

424 combustion of the OPW was observed at $600^{\circ} \mathrm{C}$, wherein the PPW there was an extra small

425 combustion peak at a temperature of $>700^{\circ} \mathrm{C}$. This is attributed to the high lignin content

426 (decomposes at high temperature) in the PPW compared to OPW which are 20 and 6.4\%,

427 respectively [7]. 


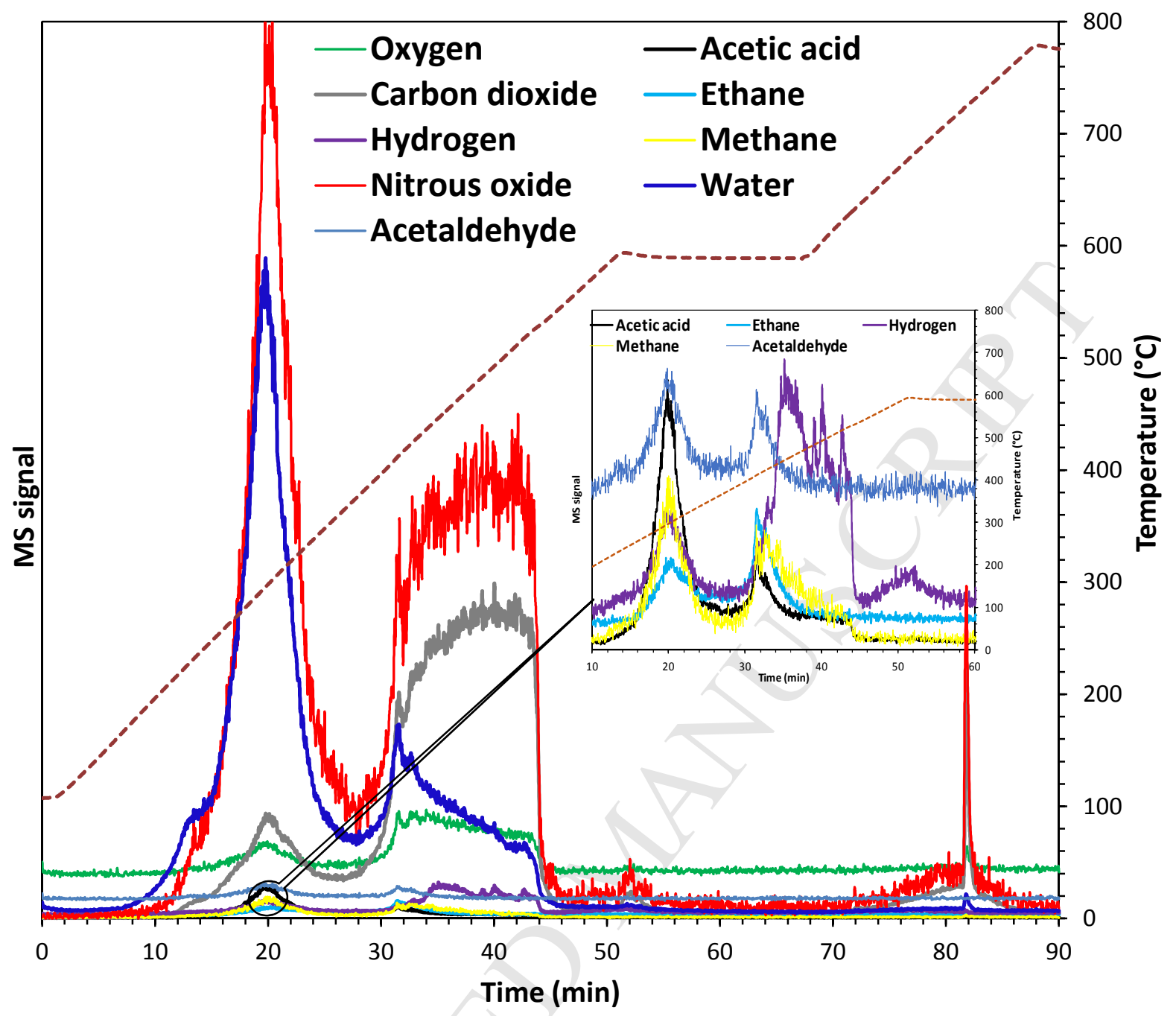

Time (min)

Figure 11: Mass spectrum profile of the gas released during potato peel waste combustion under air atmosphere with a temperature ramp of $10{ }^{\circ} \mathrm{C} \cdot \mathrm{min}^{-1}$. The temperature is shown in a dashed line.

\subsection{NOx Abatement Systems SCR with and without urea:}

The selective catalytic reduction (SCR) of NOx during the combustion of miscanthus in an air atmosphere using an only DeNO $x$ catalyst which is $\mathrm{Pt} / \mathrm{TiO}_{2} / \mathrm{ZSM}-5$ is shown in Figure 12 . The preparation of the DeNOx catalyst is shown elsewhere [24]. Interestingly, the MS profile showed that the highest gas emission is water i.e. the DeNOx catalyst did reduce the $\mathrm{N}_{2} \mathrm{O}$ emissions into $\mathrm{H}_{2} \mathrm{O}$ and $\mathrm{N}_{2}$. However, the emission level of $\mathrm{N}_{2} \mathrm{O}$ still observable as shown in Figure 12. 


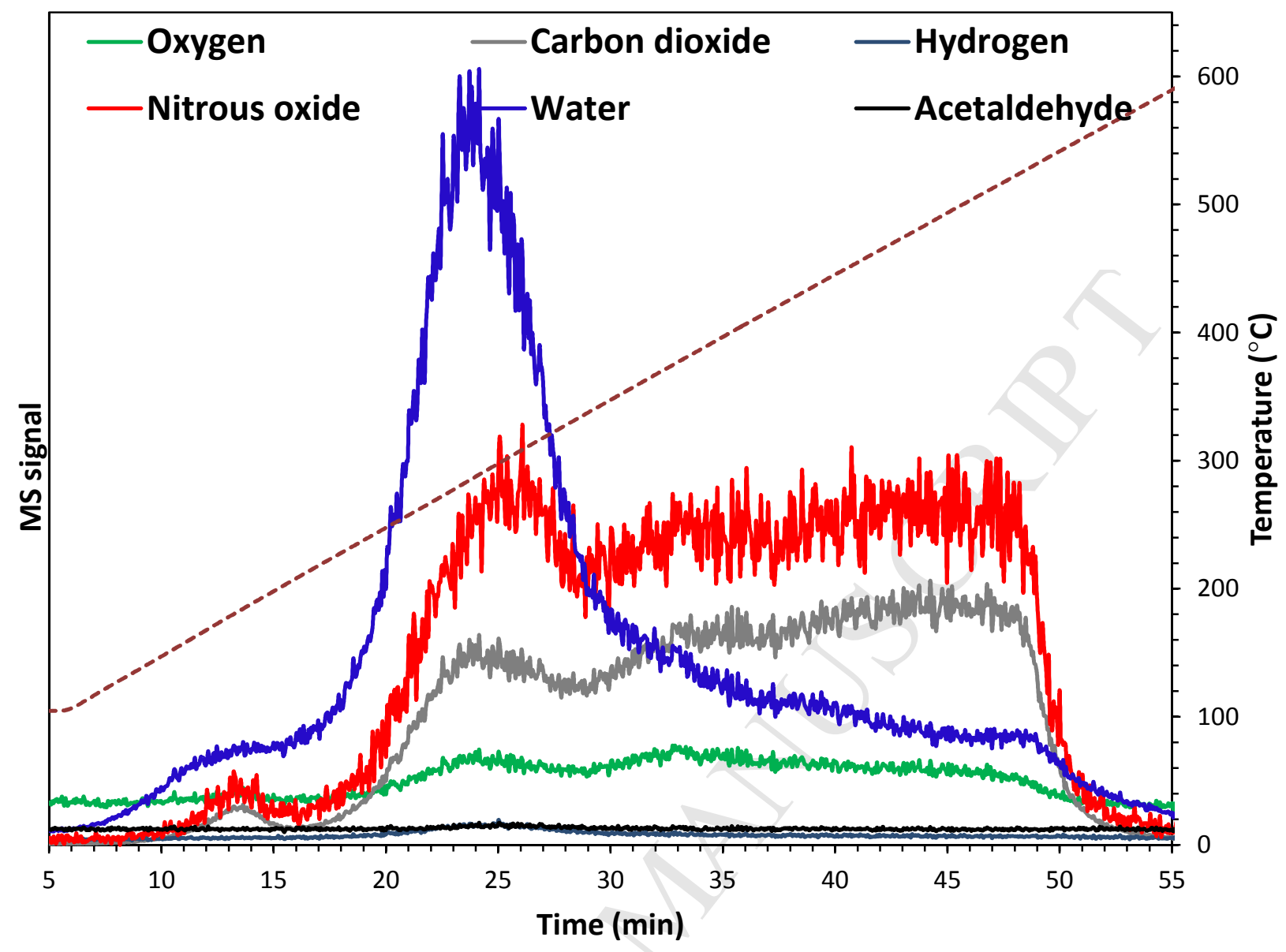

Figure 12: Mass spectrum profile of the gas released during miscanthus combustion under air atmosphere with a temperature ramp of $10^{\circ} \mathrm{C} \cdot \mathrm{min}^{-1}$ along with the addition of the DeNO $x$ catalyst. The temperature is shown in a dashed line.

442 To check the efficiency of the $\mathrm{NH}_{3}$-SCR system, the combustion test (miscanthus in air) was

443 performed with the addition of DeNOx catalyst along with urea as shown in Figure 13. It is 444 obvious that the emission level of the $\mathrm{N}_{2} \mathrm{O}$ was dramatically reduced with water is the highest 445 level of emission i.e. most of the $\mathrm{N}_{2} \mathrm{O}$ emissions were converted into water according to the 446 Equation 2 or Equation 3.

$$
\begin{aligned}
& \mathrm{N}_{2} \mathrm{O}+4 \mathrm{NH}_{3}+2 \frac{1}{2} \mathrm{O}_{2} \rightarrow 3 \mathrm{~N}_{2}+6 \mathrm{H}_{2} \mathrm{O} \quad(\text { Equation } 2) \\
& \left.\mathrm{N}_{2} \mathrm{O}+2 \mathrm{NH}_{3}+2 \mathrm{O}_{2} \rightarrow 2 \mathrm{~N}_{2}+3 \mathrm{H}_{2} \mathrm{O}+\mathrm{O}_{2} \quad \text { (Equation } 3\right)
\end{aligned}
$$


447 So by adding urea that decomposes to ammonia during the reaction along with the DeNOx 448 catalyst showed better efficiency in mitigating the NOx emissions than using only the DeNOx 449 catalyst.

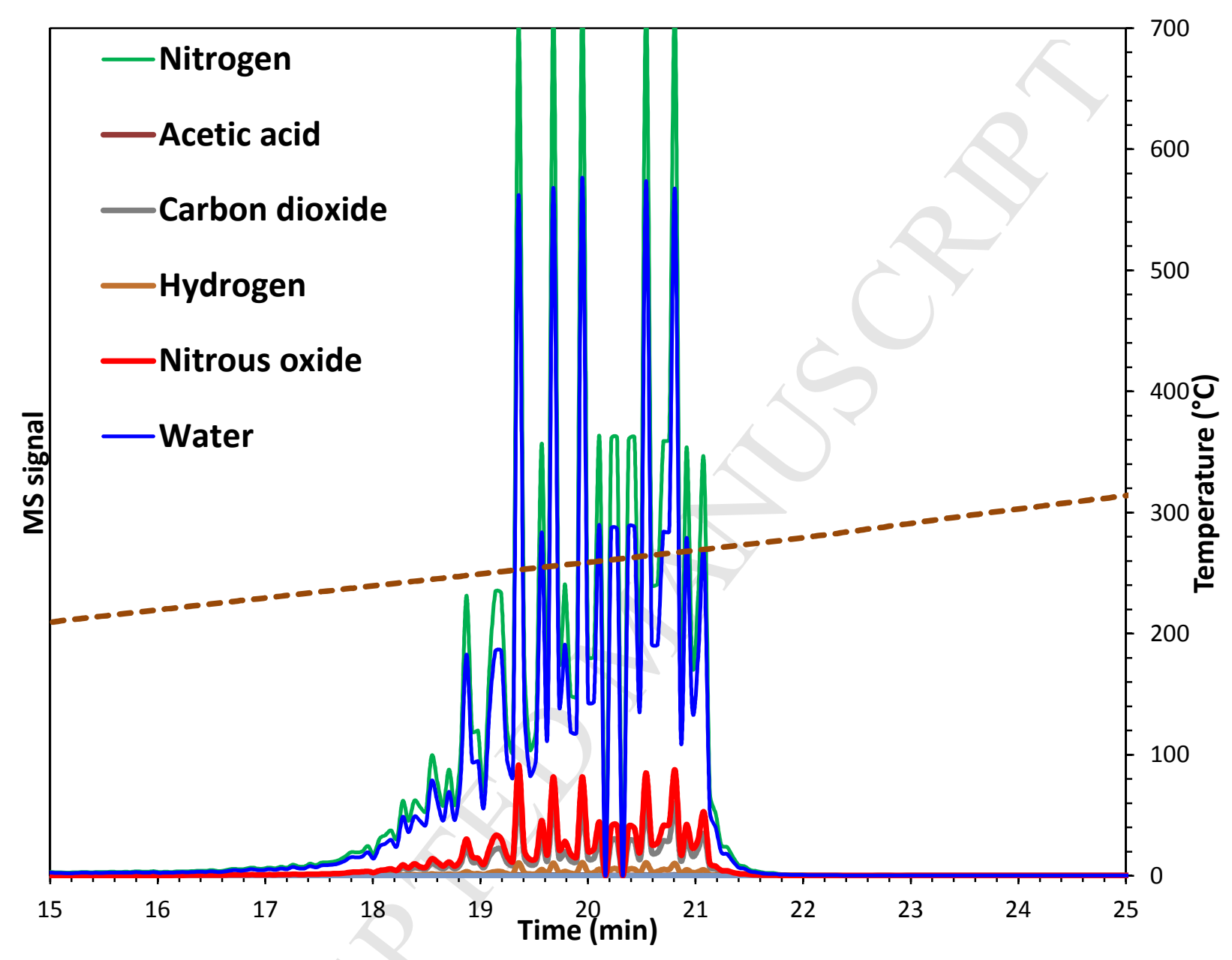

Figure 13: Mass spectrum profile of the gas release during miscanthus combustion under air atmosphere with a temperature ramp of $10{ }^{\circ} \mathrm{C} \cdot \mathrm{min}^{-1}$ along with the addition of the DeNOx catalyst and urea. The temperature is shown in a dashed line. 


\section{Conclusions}

459 Herein, three different lignocellulosic biomasses (miscanthus $\times$ giganteus, orange peel (OPW)and 460 potato peel (PPW) waste) were characterized using XRD, SEM-EDX, $\mathrm{S}_{\mathrm{BET}}$, CHNS, TGA and 461 DCS techniques. The crystalline cellulose in miscanthus is much higher than that of OPW and 462 PPW with \% crystallinity index values of $77.1,46.0$ and $24.1 \%$, respectively. Potato ash was the

463 best candidate among the three lignocellulosic biomasses of being used as a potential source of 464 potassium in the fertilizer industry with $23.8 \mathrm{wt} . \%$ of its composition is potassium, where OPW 465 showing the highest HHV (higher heating value) of $17.88 \mathrm{MJ} \mathrm{Kg}^{-1}$ among the three samples. XRD results showed that all the three biomass feedstock ashes composed of mainly potassium hydrogen disilicate and potassium chloride phases which has an impact on the combustion/pyrolysis performance. In-situ gas detection from combustion/pyrolysis of those

469 lignocellulosic biomass samples with NOx removal were studied using Mass spectrometer (MS) technique. The combustion experiments were performed under pure air or oxygen while pyrolysis under nitrogen along with the combustion of the produced biochar under air atmosphere. Unlike miscanthus and OPW combustion which occurred in two stages, the combustion of PPW showed two main combustion stages at temperature ranges of $200-300^{\circ} \mathrm{C}$ and $400-500^{\circ} \mathrm{C}$ along with a

474 small combustion peak at high temperature $\left(>700^{\circ} \mathrm{C}\right)$ due to the higher lignin content herein. The results revealed that NOx gases are the main gases emission during the combustion/pyrolysis processes. During the combustion of the three samples, different emissions were released such as nitrous oxide $\left(\mathrm{N}_{2} \mathrm{O}\right)$, water $\left(\mathrm{H}_{2} \mathrm{O}\right)$, carbon dioxide $\left(\mathrm{CO}_{2}\right)$, nitric oxide $(\mathrm{NO})$, nitrogen dioxide $\left(\mathrm{NO}_{2}\right)$, oxygen $\left(\mathrm{O}_{2}\right)$, acetaldehyde $\left(\mathrm{CH}_{3} \mathrm{CHO}\right)$, acetic acid $\left(\mathrm{CH}_{3} \mathrm{COOH}\right)$ and hydrogen $\left(\mathrm{H}_{2}\right)$ emissions with traces of benzene. While under pyrolysis conditions, emissions such as $\mathrm{N}_{2} \mathrm{O}, \mathrm{H}_{2} \mathrm{O}$, traces of $\mathrm{CO}_{2}$, two large $\mathrm{H}_{2}$ peaks (at a temperature of 580 and $700^{\circ} \mathrm{C}$ ), hydrocarbons (methane 
and ethane), acetic acid, methyl alcohol and hydrogen with traces of nitrogen oxides (NO and $\left.482 \quad \mathrm{NO}_{2}\right)$.

The in-situ mass spectrometer technique showed that by adding a DeNOx catalyst $\left(\mathrm{Pt} / \mathrm{TiO}_{2} / \mathrm{ZSM}\right.$ -

5) during the combustion, it reduced the $\mathrm{N}_{2} \mathrm{O}(\mathrm{NO} x)$ emissions by converting such emissions into $\mathrm{H}_{2} \mathrm{O}$ and $\mathrm{N}_{2}$, however, the emission level of $\mathrm{NO} x$ still observable. Thus, by coupling the DeNO $x$ catalyst with urea to construct an in-situ $\mathrm{NH}_{3}$-SCR catalytic system during the combustion, it effectively reduces the NOx emissions.

\section{Supporting Information:}

491 Figure S1: Ignition temperatures of miscanthus, OPW and PPW samples derived from the DSC curves at different heating rates under air atmosphere.

Figure S2: Burnout temperatures of miscanthus, OPW and PPW samples derived from the DSC curves at different heating rates under air atmosphere.

Figure S3: Heat liberated from miscanthus, OPW and PPW samples derived from the DSC curves at different heating rates under air atmosphere.

Acknowledgement: The authors would like to acknowledge the support given by professor David

499 Rooney through PRP and Bryden Centre at Queen's University Belfast. A.O would like to thank

500 Charlie Farrell for the proof reading of the manuscript.

501 Competing financial interests: The author declares no competing financial interests.

\section{AUTHOR INFORMATION}

\section{Corresponding Author}

$504 *$ Corresponding Author: Dr Ahmed Osman Email: aosmanahmed01@qub.ac.uk 


\section{References}

510

[1] SEIL, Miscanthus, a revolutionary biomass crop, http://www.recrops.com/miscanthus, accessed at 4pm 19-07-2016, 2016. http://www.recrops.com/miscanthus. 2016).

[2] N. Brosse, A. Dufour, X. Meng, Q. Sun, A. Ragauskas, Miscanthus: a fast-growing crop for biofuels and chemicals production, Biofuels, Bioproducts and Biorefining 6(5) (2012) 580-598.

515

516

517 [3] A.I. Osman, J.K. Abu-Dahrieh, D.W. Rooney, J. Thompson, S.A. Halawy, M.A. Mohamed, Surface hydrophobicity and acidity effect on alumina catalyst in catalytic methanol dehydration reaction, J Chem Technol Biot 92(12) (2017) 2952-2962.

518 [4] A.I. Osman, J.K. Abu-Dahrieh, M. McLaren, F. Laffir, P. Nockemann, D. Rooney, A Facile Green Synthetic Route for the Preparation of Highly Active $\gamma-\mathrm{Al}_{2} \mathrm{O}_{3}$ from Aluminum Foil Waste, Nature Scientific Reports 7(1) (2017) 3593. [5] A.I. Osman, J.K. Abu-Dahrieh, A. Abdelkader, N.M. Hassan, F. Laffir, M. McLaren, D. Rooney, Silver-Modified $\eta$-A12O3 Catalyst for DME Production, The Journal of Physical Chemistry C 121(45) (2017) 25018-25032.

[6] E.G.A. Forbes, D.L. Easson, G.A. Lyons, W.C. McRoberts, Physico-chemical characteristics of eight different biomass fuels and comparison of combustion and emission results in a small scale multi-fuel boiler, Energy Conversion and Management 87 (2014) 1162-1169.

[7] S. Liang, A.G. McDonald, Chemical and Thermal Characterization of Potato Peel Waste and Its Fermentation Residue as Potential Resources for Biofuel and Bioproducts Production, Journal of Agricultural and Food Chemistry 62(33) (2014) 8421-8429.

[8] I. Ahmed, M.A. Zia, M.A. Hussain, Z. Akram, M.T. Naveed, A. Nowrouzi, Bioprocessing of citrus waste peel for induced pectinase production by Aspergillus niger; its purification and characterization, Journal of Radiation Research and Applied Sciences 9(2) (2016) 148-154.

[9] D. Wu, Recycle Technology for Potato Peel Waste Processing: A Review, Procedia Environmental Sciences 31(Supplement C) (2016) 103-107.

535 [10] E.B. Ledesma, C.-Z. Li, P.F. Nelson, J.C. Mackie, Release of HCN, NH3, and HNCO from the Thermal Gas-Phase Cracking of Coal Pyrolysis Tars, Energy \& Fuels 12(3) (1998) 536-541. [11] K.-M. Hansson, J. Samuelsson, C. Tullin, L.-E. Åmand, Formation of HNCO, HCN, and NH3 from the pyrolysis of bark and nitrogen-containing model compounds, Combustion and Flame 137(3) (2004) 265-277. modelling of NOx precursors release (NH3 and $\mathrm{HCN}$ ) in fixed-bed biomass combustion conditions, Fuel 222 (2018) 529-537.

543 [13] H. Zhan, X. Zhuang, Y. Song, X. Yin, C. Wu, Insights into the evolution of fuel-N to NOx precursors during pyrolysis of N-rich nonlignocellulosic biomass, Applied Energy 219 (2018) 2033.

[14] P. Glarborg, A.D. Jensen, J.E. Johnsson, Fuel nitrogen conversion in solid fuel fired systems, Progress in Energy and Combustion Science 29(2) (2003) 89-113.

[15] I.T.a.P.I.D.O.o.A.Q.P.a.S.U.S.E.P.A. Clean Air Technology Center (MD-12), Nitrogen Oxides (NOx), Why and How They Are Controlled, (1999). 
550 [16] Department for Environment, Food and Rural Affairs \&Department for Transport, Improving 551 air quality: national plan for tackling nitrogen dioxide in our towns and cities, accesed at 7/9/2017

55210 am., https://consult.defra.gov.uk/airquality/air-quality-plan-for-tackling-nitrogen-dioxide/ (5 553 May 2017).

554 [17] A.I. Osman, A. Abdelkader, C.R. Johnston, K. Morgan, D.W. Rooney, Thermal Investigation 555 and Kinetic Modeling of Lignocellulosic Biomass Combustion for Energy Production and Other Applications, Industrial \& Engineering Chemistry Research 56(42) (2017) 12119-12130. [18] A.I. Osman, A.T. Ahmed, C.R. Johnston, D.W. Rooney, Physicochemical characterization of miscanthus and its application in heavy metals removal from wastewaters, Environmental Progress \& Sustainable Energy 37(3) (2018) 1058-1067.

560 [19] I. Bicu, F. Mustata, Cellulose extraction from orange peel using sulfite digestion reagents, 561 Bioresource Technology 102(21) (2011) 10013-10019.

562 [20] J. Kaknics, F. Defoort, J. Poirier, Inorganic Phase Transformation in Miscanthus Ash, Energy

563 \& Fuels 29(10) (2015) 6433-6442.

564 [21] D.P. Mishra, S.K. Das, A study of physico-chemical and mineralogical properties of Talcher

565 coal fly ash for stowing in underground coal mines, Materials Characterization 61(11) (2010)

566 1252-1259.

567 [22] C.M. Santos, J. Dweck, R.S. Viotto, A.H. Rosa, L.C. de Morais, Application of orange peel 568 waste in the production of solid biofuels and biosorbents, Bioresource Technology 569 196(Supplement C) (2015) 469-479.

570 [23] B. Zapata, J. Balmaseda, E. Fregoso-Israel, E. Torres-García, Thermo-kinetics study of 571 orange peel in air, Journal of Thermal Analysis and Calorimetry 98(1) (2009) 309.

572 [24] A.I. Osman, J.K. Abu-Dahrieh, F. Laffir, T. Curtin, J.M. Thompson, D.W. Rooney, A

573 bimetallic catalyst on a dual component support for low temperature total methane oxidation,

574 Applied Catalysis B: Environmental 187 (2016) 408-418. 


\section{Potential Referees}

\section{Professor Rafael Luque}

Deputy Head of Department

Departamento de Química Orgánica

Universidad de Córdoba

Campus de Rabanales

Edificio Marie Curie (C-3)

Ctra Nnal IV, Km 396

Córdoba (Spain) E-14014

e-mail: q62alsor@uco.es

Tel: $\quad+34957211050$

Fax: $\quad+34957212066$

\section{Mustafa Versan Kok}

Department of Petroleum and Natural Gas Engineering, Middle East Technical University, Ankara, Turkey

Tel.: +4687908251

E-mail address: Kok@metu.edu.tr

\section{Armando G. McDonald}

Department of Forest, Rangeland and Fire Science, University of Idaho, Moscow, Idaho 83844-1132, United States

Tel: +1 208885 9454. Fax: +1 208885 6226. E-mail: armandm@uidaho.edu.

\section{Shaobo Liang}

Environmental Science Program, University of Idaho, Moscow, Idaho 83844-3006, United States

Email:sshliang@gmail.com 


\section{Highlights:}

- NOx gases were generated during the combustion process under air atmosphere.

- $\mathrm{Pt} / \mathrm{TiO}_{2} / \mathrm{ZSM}-5$ did reduce the NOx emissions to a manageable level.

- Coupling the DeNOx catalyst with urea during the combustion effectively reduced NOx emissions.

- $\mathrm{NO} x$ emissions were converted into nitrogen and water over $\mathrm{Pt} / \mathrm{TiO}_{2} / \mathrm{ZSM}-5$ coupled with urea during the combustion. 